\title{
Performing Ornaments in English Virginal and Harpsichord Music (Based on the Study of Original Interpretation Instructions) ${ }^{*}$
}

\author{
A. A. Panov ${ }^{1}$, I. V. Rosanoff ${ }^{1,2}$ \\ ${ }^{1}$ St. Petersburg State University, \\ 7-9, Universitetskaya emb., St. Petersburg, 199034, Russian Federation \\ ${ }^{2}$ Saint Petersburg Rimsky-Korsakov State Conservatory, \\ 3, Teatralnaya sq., St. Petersburg, 190000, Russian Federation
}

For citation: Panov, Alexei, and Ivan Rosanoff. "Performing Ornaments in English Virginal and Harpsichord Music (Based on the Study of Original Interpretation Instructions)". Vestnik of Saint Petersburg University. Arts 10, no. 1 (2020): 41-67. https://doi.org/10.21638/spbu15.2020.103

The focus of the article is centered on the problems of performing ornaments in English virginal music of the Elizabethan and several first decades of Post-Elizabethan time. The paper presents a comparative analysis of information from historical sources, representing the views of early British virginalists regarding the methods and rules which deal with the interpretation of the unique, for that period, ornament signs. Special attention is given to the MS Res. 1186 located in the Bibliothèque nationale de France. Historically, the situation was such that except for information from the MS materials by Edward Bevin (c1630), science did not have any information directly related to the execution of virginal ornamentation. A critical review is undertaken of the scientific literature of the $19^{\text {th }}-21^{\text {st }}$ centuries, devoted to the interpretation of early English virginal music, as well as the review of information from reference and encyclopedic literature. Numerous inaccuracies, discrepancies and even serious errors in the interpretation and presentation of materials from early sources by modern researchers are revealed. As a result a generalization is provided in which it is stated that there are many possibilities for performing virginal ornaments marked by double oblique strokes, but not playing them from the above auxiliary note except in the cadential (semi- and quasi-cadential) contexts. The article also examines the possible correlations between performing principles of English virginalists and the practical recommendations from the well known Spanish, Italian, German and French treatises from the analyzed period.

Keywords: Ornamentation, English virginal music, Edward Bevin, William Byrd, John Bull, Orlando Gibbons, Thomas Tallis, John Blow, Blitheman.

Do I envy those jacks, that nimble leap

To kiss the tender inward of thy hand,

Whilst my poor lips, which should that harvest reap. At the wood's boldness by thee blushing stand!

William Shakespeare ${ }^{1}$

Among numerous scientific and practical aspects in the field of Early Music, especially in the sphere of performing ornaments, the phenomenal heritage of English virginalists

\footnotetext{
* The reported study was funded by RFBR according to the research project № 18-012-00208.

1 Sonnet cxxviii, cited from: [1, p. 4, footnote 11].

(c) Санкт-Петербургский государственный университет, 2020
} 
repertory (c1550-1700: three periods) presents a very specific, complicate, and one may say, tricky problem. The deeper some outstanding contemporary scholars, music editors, performers and those from the nearest past dig into it, the less certain the results become of the research. Modern research has great opportunities because it has the possibility to access an infinite number of manuscripts stored not only in British museum and other libraries in England, but also in different countries. To verify this it is sufficient to examine papers on the topic, published during the last thirty years [2-10].

Almost all known and available materials on virginalist's ornamentation are considered in these works (currently we do not touch upon some rather serious contradictions found in the named works - this will be addressed later). The "tricky" side of this issue on the one hand is that the virginal $[2$, p. 6$]$ music of the last quarter of the $16^{\text {th }}$ and especially the first half of the $17^{\text {th }}$ centuries was, we could say, presented by innumerable compositions. They were mostly abundantly filled with ornaments. On the other hand (except two cases, dealing with the "Graces in play" by Ed. Bevin, c1630: this issue will be discussed in detail below and by H.Purcell's "Rules for Graces," 1696) none of the virginalists offered any explanations for the manner of performing the signs of graces (single, double, and sometimes triple oblique strokes, very rarely quadrouple ones; examples are given below). It seems that every musician of that period perfectly knew how to deal with one or another ornament sign, or - as musicians of those times often remarked - knowledge of interpreting these signs had been passed more often from teacher to scholar verbally within the boundaries of the master's school.

Until the time when reliable historical material will be discovered where the principles of executing virginal ornaments receive a detailed explanation (in our opinion we are quite sure that such material will be discovered), scholars are compelled to explore indirect ways (using external sources or secondary evidence) of research, trying to find the historically correct manner of performing early English virginal ornaments.

Howard Ferguson's reasons: "Surprisingly enough, however, neither [of the two signs, the single stroke and the double stroke] is explained or even mentioned by any contemporary authority, and both often occur inconsistently in different sources of the same piece." Ferguson shows how the single-stroke ornament signs were marked by the early English musicians: “ $f, f, \sigma, ?, \phi$ " and the double-stroke ones $-“ f, f, \xi, \geqslant$ [2, p. 11].

Half a century later Alan Brown (2004) summarized that the performance of ornaments "has been the subject of widest debate in the case of the virginalists, for the obvious reason that there is no trustworthy contemporary explanation of the two familiar signs, the single stroke and the double stroke through the stem" [6, p.48] (authors' underlining. - A.P., I.R.). The same notion following Brown's article is expressed in thesis like form a few years later by Stephen Rose (2012): "Over three centuries after Purcell's time, however, scholars have no option but to try to garner clues about ornamentation from written sources such as explicatory tables and annotated manuscripts." In his publication Rose adhered to his outlined plan according to which it is necessary to "summarize the existing state of research on Purcell's keyboard ornaments," by bringing the issue closer to a logical solution, and also by writing a section which "explores some avenues for future research on the hitherto little-studied area of vocal embellishments" [10, p. 140].

These "oblique strokes", mentioned above, can practically be found in any pieces composed from the second half of the sixteenth to the third quarter of the eighteenth century, 
and they were designed for performing not only on the keyboard instruments. Here it is necessary to show some early examples and to discuss contradictory and inconsistent versions of ornamentation in one and the same piece found in different sources. Despite the fact that verbal explanations, even the most detailed ones, provide an idea of the encountered discrepancies, however, they are not able to present the latter convincingly as a comparative analysis of the musical material itself. Consequently, we believe that musical examples should be presented widely enough, and we are adhering to this notion.

Ornament signs represented exclusively by double oblique strokes are abundantly incorporated, for example, in the "Pauana" named by William Byrd as "The Earle of Salisbury" published in the unique edition "Parthenia, or the Maydenhead of the first musicke" (Ex. 1). It should be mentioned that ornaments designated by double oblique strokes were more common during the Golden Age of the virginalist period than the single oblique strokes.

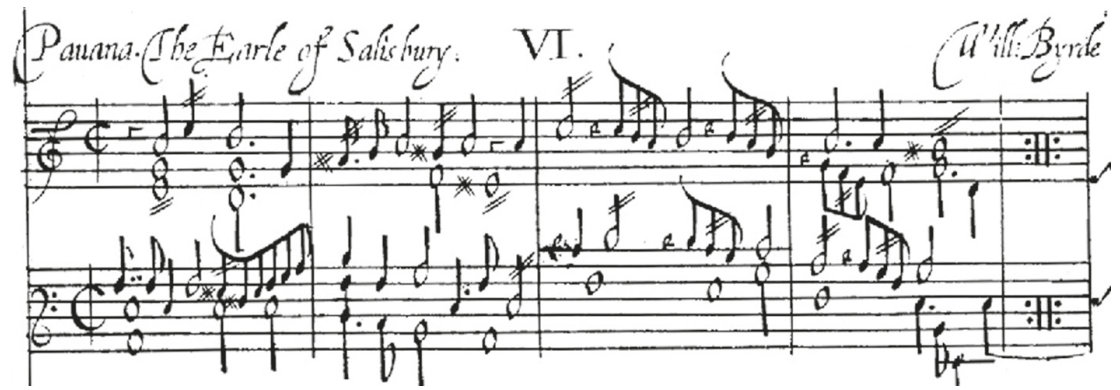

Example 1. William Byrd. "Pauana" from "Parthenia or The Maydenhead of the first Musicke that euer was printed for the Virginalls $<\ldots>[11]$

Suggestions for choosing the execution of the ornaments specific to that period are given in summary form at the end of this part of the paper, but even now it may be noted that if we refer to scholarly publications we shall see that the differences at first look are not so essential in the recommendations for their execution due to the lack of reliable historical information as has been previously stated. However, every author has his own point of view, and personal scholarly reason to make proposals. It is namely in these sections, with the proposals, where quite significant deviations are found especially pertaining to the execution of the double-stroke ornament realized in the vattern of a short (four-note) trill performed beginning from the upper auxiliary note: er of its rhythmic form. This interpretation from our point of view does not correspond stylistically to the golden virginal era. The discussion of the manner of performing "threenote" and "four-note" trills constitutes one of the fundamentally important issues in virginal music approximately between 1570-1630. The appearance of the "four-note" execution of the trill should be dated later, and it was most likely associated with the French and also the English harpsichord performance practice ${ }^{2}$. There is no evidence of its use in

${ }^{2}$ We are certainly not speaking of the trill supplied with any kind of cadential closing / suffix. The trill with a cadential ending (fully written out in notes in music and in diminution practice) had been used abundantly (as an ornamental cliché) from the early $16^{\text {th }}$ century. For example, in Ganassi's "Opera

Intitulata": "基 cadential ending are found practically everywhere; sometimes they were even used by the virginalists as in Frescobaldi's toccatas in thematic material. 
earlier times in the music for virginals (1530-1650). We can find any kind of (the socalled) written-out in notes ornaments: the slide, the turn (in any of its form), the repetitions, the passaggios, the cadential and quasi-cadential patterns but not one scholar has been able to discover by chance or deliberately the four-note written out trill pattern ${ }^{3}$.

Howard Ferguson, for example, shows eleven possibilities (Ex. 2) of performing the double-stroke ornament. Some other authors do not even try to offer any specific solutions, for instance, as is done by Denis Stevens' in his edition of Th. Tallis' keyboard music $[14]^{4}$.

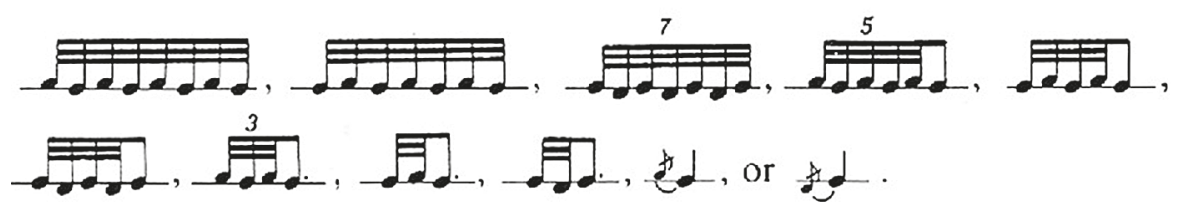

Example 2. "Some of the possibilities" of executing the double-stroke ornament in virginal music as proposed by H. Ferguson [2, p. 12, example No. 14]

In the above "Pauana," Byrd applies the double-stroke ornaments (presumably a shake/trill which could have been executed in a variable range of interpretations) for several purposes: firstly, he might have used them not only to enhance the metric pace and distinguish syncopated notes, but also to sustain longer ones (m1), secondly, to animate the quavers, especially in $\mathrm{m} 3$ and 4 , thirdly, to enliven the music structure providing an architectonic integrity.

${ }^{3}$ Just one example of contemporary judgment. Janet Pollack [13, p. 252] first confirmed that "From these sources [the researched sources in her work] one can conclude that the shake may begin either on the written note, or the auxiliary note, or perhaps, as other scholars have suggested, be played as a rapid grace note on or before the beat." Next follows a partly indisputable statement: "However, Byrd with his writtenout ornaments in Parthenia makes clear that the earlier repertory expected the double-stroke ornament to begin on the auxiliary note. The number of repercussions varies according to tempo, placement, and the performer's agility." Pollack could not help but notice that Byrd's written-out ornaments (in our case trills) in Parthenia and everywhere else are always with a cadential or semi / quasi-cadential suffix / ending. This certainly concerns the virginal music of other composers too. It might be that in Pollack's example Bevin's double-stroke sign is erroneously without a small "tail," indicating the cadential turn, and because of this obvious mistake, the author of the dissertation concluded that the double-oblique stroke may be interpreted in Byrd's music as ordinary (thus, "the simple trill" - Fr. Neumann's term), starting from the upper auxiliary note. It must be repeated here that there is not one written-out trill without a cadential ending found in the virginal pieces of the Golden Age. Contrariwise, if the double-stroke ornament is written in a textually cadential situation, in our opinion, it is musically logical to follow Byrd's written-out examples. But there is no confirmation that "the earlier repertory expected the double-stroke ornament to begin on the auxiliary note," as Pollack states.

4 "Ornaments, shown by short strokes drawn through the note-stems, may be interpreted according to the will - and the ability - of each player. A careful comparison of the five sources of Felix namque (II) shows that no two players agreed on the matter of placing ornaments, which were probably short trills, mordents, or slides. The context, both melodic and harmonic, should be the main factor in deciding which type of ornament to use." Almost the same consideration is met in the edition of Thomas Tomkins's virginal music where the method of performing ornaments is explained as: "All ornaments are given as they appear in the manuscripts. The method of their performance has still to be discovered but it is probable that $\geqslant$ (the sign most commonly used) is merely an indication that an ornament of some kind should be played, the particular ornament being left to the performer's sense of style" [15, p.xv]. A first step to discovering the meaning of the virginal ornaments already had been quite authoritatively treated in the works of Ed. Dannreuther [16] and A. Dolmetsch [17]. 
Numerous ornamentation signs (single and double-strokes) are used in the anonymous MS copy (Rés.-1186), c1630-38, for example, in the Psalm Nº 67 (Ex. 3).

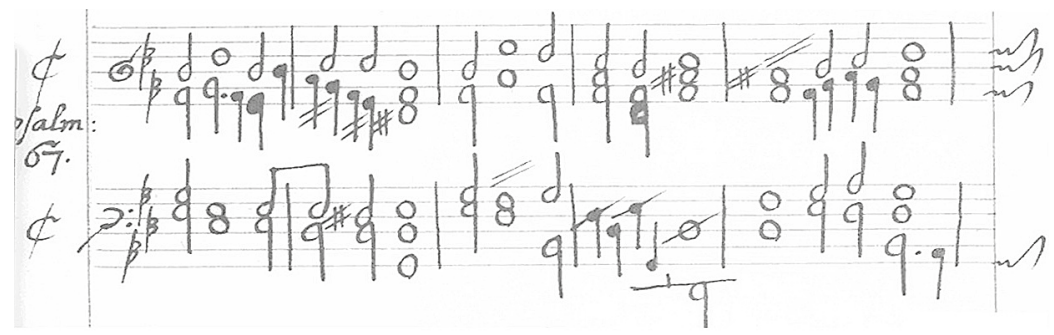

Example 3. Rés.-1186 in the Bibliothèque nationale de France (library No according to the stamp the number is "18546"), with a note written perhaps by a librarian "Recueil de pièces pour virginal" and another note: "Musique de Clavier (Virginal). Divers auteurs Anglais"5

In the same MS one may find, along with one-and-two oblique stroke ornament signs, the very rare four-stroke ones applied to notes in a popular piece by R. Creigton "Lift up your eyes to $y^{e}$ skies etc." dated "Feb. 25, 1635" (Ex. 4) ${ }^{6}$. Scholars only guess what notes should be played instead of these four-stroke ornament signs.

5 This unique holding contains more than 200 pieces (anonyms and with author-names such as Th. Bateson, Th. [?] Wilkinson, Th. Morley, J. Dowland, R. Creigton, H. Loosemore, W. Daman, W. Byrd, Th. Tallis, O. Gibbons, Th. Mudd, R. Clarke, J. Bull, J. Lugge, Th. Tomkins, T. Williams, W. Damon). Alan Brown in his work [6, p. 64] does not risk attributing the author of the manuscript. Concerning this issue we read: "The kind of repertory covered by an English keyboard player in the 1630s is preserved in Paris 1186, a manuscript of nearly 200 pieces compiled by "R. Cr." (who has not been identified). However in the article "Sources" [18, p. 38] in brackets it is said that Rés.-1186 had been" (compiled by R. Creighton, c1630-40)". Stated in the form of an assumption, Ian Spink adheres to the same opinion: "The elder Creighton [Robert Creighton (1593-1672)] was probably the ' $R$. Cr.' who signed several pieces in a keyboard manuscript in the Bibliothèque Nationale (1186; c1635-8) and was responsible for compiling the volume" [19, p. 660]. Creighton did in fact include in the MS Rés.-1186 some of his music. Example 4 distinctly shows that his handwrit-

ing had its own specific features. Very characteristic is Creighton's manner of connecting quavers:

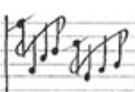

Practically in every piece we can find these features.

6 The prevailing view is that the ornaments marked by the single stroke are used less often than the double stroked ones (cf. Ferguson [2], Hunter [5]). Particularly revealing is Hunter's reasoning: "there is a remarkably high percentage of single strokes in Duncan Burnetts Virginal Book. This is exceptional, however. In many sources the sign is not used at all and in others occurrences are rare. In Parthenia, for instance, it is used in only two of the twenty-one pieces" [5, p.71]. In 2001 [4, p.710], the author only states "the single stroke occurs with much less frequency." In her dissertation J. Pollack asserts in the next statement that "Significantly nowhere [sic] in the repertory is the single stroke used when not accompanied by a double stroke suggesting that the single stroke was intended to clarify in some way the more frequent double stroke" [13, p. 247]. However, if we turn to MS Res. 1186 where more than 200 pieces are entered, we shall notice that the above generalizations expressed with regard to the use of single stroke ornament signs do not fully correspond to the true state of the virginal music. Just a few examples: 1) pieces exclusively with single stroke ornament signs: "The Nightingale, so soone as Aprill springeth" (Bateson), "A sea Nymph sate upon the shore" (Wilkinson); 2) with both single and double stroke ornament signs: "Come follow mee faire Nymphes, come" (Bateson); 3) exclusively with double stroke ornament signs: "O sleepe, o sleepe fond fancie" (Morley), \&c. This list can be substantially expanded because we picked just several pieces only from the beginning of the MS. 


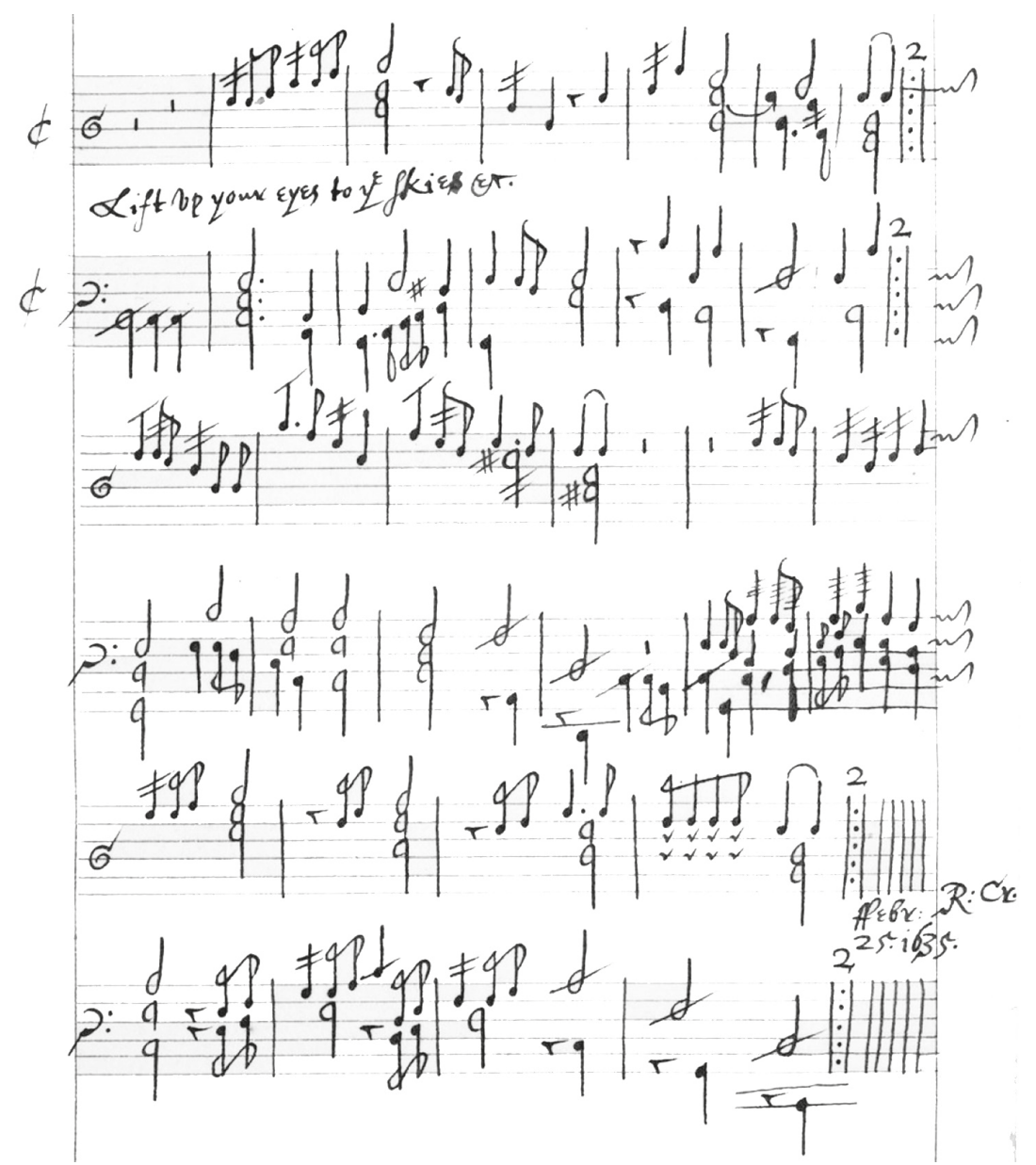

Example 4. Res.-1186, p. 21: R. Creigton "Lift up your eyes to ye skies etc., dated "Febr. 25, 1635" and signed "R: Cr"

This manuscript, like many other MS, also provides an opportunity to compare the ornament signs in some of the works included in it with reliable author's versions available among the works of a certain composer. Our attention was drawn to the harpsichord piece entitled My Lord Willbee's [sic] wellcome home, entered in Res. 1186 on p. 64. Most likely this piece had been inserted here by an anonymous author. More important is that its text can be compared with William Byrd's piece (practically with the same title: Lord Willobies Welcome Home) from My Ladye Nevells Booke of Virginal Music, a MS completed by Byrd in 1591. The music of both versions, one may venture to say, coincide in whole (Ex. 5). There is not enough space to provide a full-size comparison; therefore, we must restrict ourselves to the comparison of the signs of ornamentation in individual bars of the upper voice.

First of all, it is very uncommon for us (and possibly not only for us) that in $\mathrm{m} 2$ in Res. 1186 in this piece an $\mathrm{f}$-sharp is written! Thus, the first two bars sound in G major changing to the original $g$ minor in the third bar. Next, beginning from $\mathrm{m} 5$ there are single-stroke ornaments added in Res. 1186. They could indicate that either an appoggiatura from below could be played or less likely that they might be interpreted as slides. Starting 


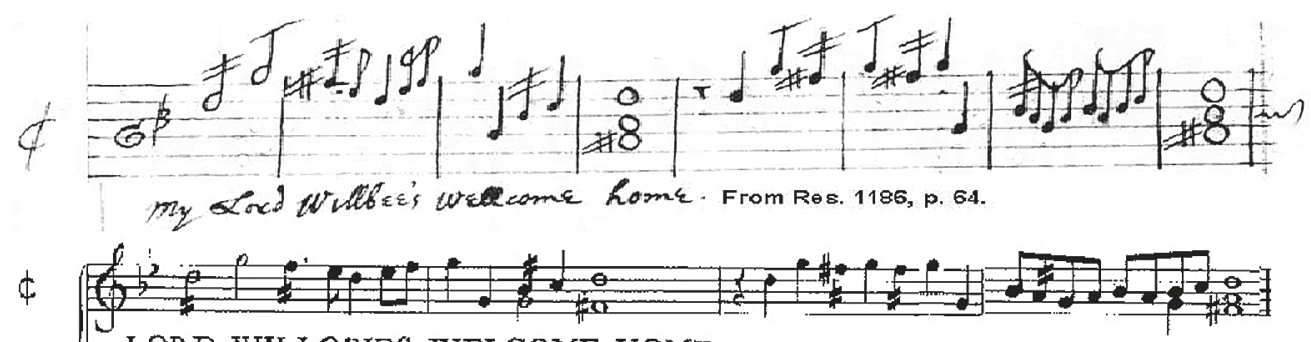

LORD WILLOBIES WELCOME HOME. My Ladye Nerells Booke of Virginal Musi
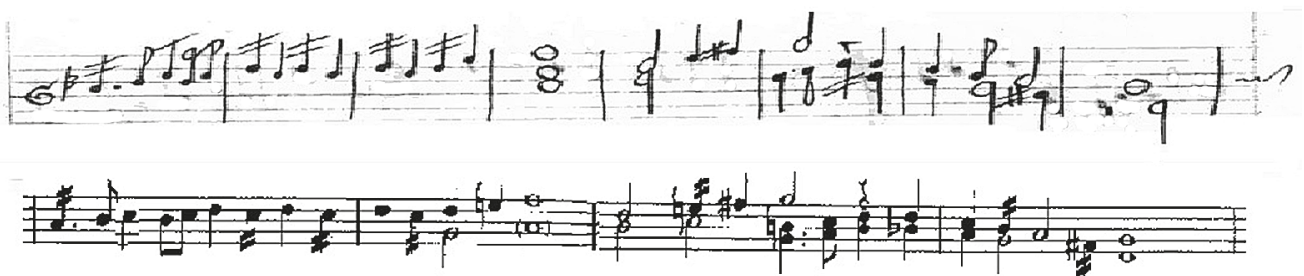

Example 5. Res.-1186 My Lord Willbee's wellcome home compared with Lord Willobies Welcome Home from My Ladye Nevells Booke of Virginal Music by William Byrd (1591) - lower line

from $\mathrm{m} 7$, something strange is happening with the meter, because in My Ladye Nevells Booke the double-stroke shakes (?) are shifted from the metric strong parts of the measure to the weak parts, or maybe the copyist changed the places of these signs (?). This occurs further throughout the piece. By shifting the ornaments Byrd possibly wanted to enliven the character of the music so that it would portray a particularly agitated mood ("welcome home"). Lastly it goes without mentioning that ornaments written in some places in one source (Res. 1186) are not found in the other one.

The first attempts to determine the manner of performing ornaments in virginal music according to our knowledge date back to the middle of the $19^{\text {th }}$ century when Louise Farrenc participated in the publication of Parthenia [20, p.5]. A "careful study" of ornaments convinced L. Farrenc that in the case when no reliable information can be obtained, the explanations of their interpretation would be generally acceptable if one refers to Purcell's recommendations [“dont nous n’avons trouvé nulle part l'explication, et les avoir toutefois comparés avec ceux employés dans le recueil des pièces de Purcell, nous avons acquis la conviction que leur interprétation doit être, eu général"]. According to $\mathrm{M}^{\mathrm{me}}$ Farrenc "for the small oblique line, a mordent [un pincé] [should be understood, i. e. M thus: ]; for the two small parallel [oblique] lines, a tremblement (trille) without termination [thus: sans termination $\left.{ }^{7}\right]$; for the three small lines, finally, a prolonged Trill extended to the termi-

7 This interpretation is taken from van den Borren's book where the author comments on $\mathrm{M}^{\mathrm{me}}$ Farrenc's explanation of the execution virginal ornament signs [1, p. 146-7]. However, none of the authors specify exactly what this realization could have meant: it could be a trill beginning from the main-note (for those times it was very common), or it could have been an upper-note trill. But since L. Farrenc is reasoning in the context of Purcell's "Rules for Graces" (1696) most probable she has in mind the performance of the trill beginning with the upper auxiliary note. 
nation [thus:

lection" [i. e. in Orlando Gibbons' Courante:

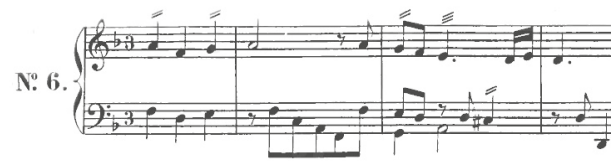
[22, Ier. Recueil, p. 14].

If $\mathrm{M}^{\mathrm{me}}$ Farrenc earlier could not find an answer in her study, why Edward F. Rimbault omitted practically all ornament signs in his edition of Parthenia [23], in on our part we are unable to understand how can it be worked out that having cited namely Purcell's recommendations accumulated in the form of a table (Ex. 6) provided to his "Choice Collection

H. PIRCELL, Pieces puer fo Clavecun.

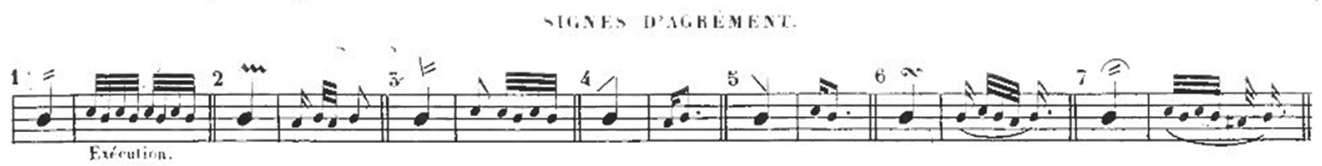

Example 6. Table of executing ornaments provided for the performance of "Pièces pour le Clavecin par Henri Purcell” [24, p. 1]

of Lessons for the harpsichord or spinnet (Collection choisie de Pièces pour le clavecin ou l'épinette; Londres, 1696" [24, p. 1]), $\mathrm{M}^{\mathrm{me}}$ Farrenc confused these interpretations.

Special attention should be paid here to the objective fact that Purcell's recommendations on interpreting ornaments taken from his "Rules for Graces" [21] are cited in Farrenc's edition in full accordance with their exact face value. All the more incomprehensible becomes the substitution of Purcell's execution of the single-oblique ornament signs (his "fore fall" and "back fall"; thus appoggiaturas from below and from above), by mordents in $\mathrm{M}^{\mathrm{me}}$ Farrenc's recommendations. It is also questionable that the shakes should be executed as long ones, and in Parthenia it is impossible to meet Purcell's "plain note \& shake", namely:

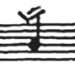

Moreover, L.Farrenc reckons that Purcell's ornament listed as number 3

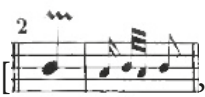
thus Purcell's "beat", i. e. mordent beginning by the lower auxiliary note]

might be used in Parthenia? This is only one part of the matter, thus the connection of Purcell's instructions to early virginal music (1612/13). Here, as is shown, it is indeed generally inappropriate to follow blindly Purcell's "Rules for Graces." The second part concerns the reality which we face in performance practice and in scientific research: some scholars have suggested that there is reason to assume that an ornament marked with a single oblique stroke might imply a mordent or a slide ${ }^{8}$, just as it was suggested by L. Farrenc. As a result it

${ }^{8}$ It began with the publication of Edward Dannreuther's solidly founded research "Musical Ornamentation" [16, p. 18] where the author states that "The single sign - occurs in early MSS. of music for the Virginals (Her Majesty's Library, Buckingham Palace, and elsewhere), where it is meant for a slide of a third upwards, for a short appoggiatura from below or from above, or now and then for a mordent (semishake, with the lower diatonic accessory)." His lead, based on the study of different sources, had been directly 
follows that both French musicians (L. and A. Farrenc) were not only the first to apply original early recommendations without any mistakes (in our case Purcell's table arranged by them as an example in one line) to the execution of ornaments in his music, but also gave start to an unending row of controversies, debates, unconfirmed treatments of facts and unsuitable amendments of historical material which took place in future scholarly works and performances of ornaments in the music of the virginal and Purcellian eras. The mentioned "controversies" began already some forty years after Farrenc's publications.

Charles van den Borren, for example in his very competent for those times and interesting work "The Sources of Keyboard Music in England," [1] does not agree with L. Farrenc's suggestions of interpreting virginal ornaments. In his study Borren confirms his point by referring to the information presented by "Messrs. Fuller Maitland and Barclay Squire" who "are not in complete agreement with $\mathrm{M}^{\mathrm{me}}$. Farrenc." From their part the named English scholars based their concept on the study by Dannreuther [16, p.18]. "They consider that the sign $T-$ Borren continuous $<\ldots>-$ ought to be interpreted as

followed by J. A. Fuller Maitland and W. Barclay Squire in their edition of The Fitzwilliam Virginal Book [25]. Many authors in later works adhered this lead. For example, Thurston Dart in his edition of John Bull's virginal music explains in the "Introduction" that the ornament sign with single oblique stroke "seems to mean 12. [a slide]" [26, p.xvi]. An interpretation, founded on the study of contemporary publications, is presented by Alan Brown [6, p. 49] where the author shows the result of his research of this issue in the form of a table with different possibilities of interpreting the single stroke virginal ornament: $=$ or $=$ Comparing with Dannreuther's solution only the short appoggiatura from below or from above is not mentioned by Brown. On the other side, Desmont Hunter [5, p.71] holds the opinion that in "retroactive consideration" the single stroke ornament signs were "probably associated also with one-note graces" which from our point of view is more than likely. Regrettably in this special article dedicated by Hunter to the study of "The Application of (Ornamental) Strokes in English Virginalist Music" the author arguments his point of view applying to the most important historical data found in François de Prendcourt's "The Marks in this Book...", which were preserved in MS and copied by Roger North (detailed information on Prendcourt is available in the publications by Michael Tilmouth [27] and Edward T. Corp [28]). In an attempt to confirm his idea that the single stroke could be realized as a slide, Hunter turns to "Prendcourt's interpretation of graces (c1700)." But in Prendcourt's "Marks in this Book..." the slides are NOT written as a single stroke! They are marked as small vertical wavy lines:

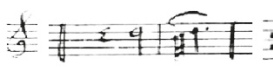

p. 304-5]) just like the arpeggiation is shown in a similar larger wavy vertical line: $\{$. Thus from the two sources presented by Hunter as arguments only "in Edward Bevin's idiosyncratic 'Graces in play' (c1630)," the application of the single stroke is realized as a slide. To this it may be added that in the next generation of "virginalists / harpsichordists" a slide marked as a single stroke written through a third is shown in Purcell's "Rules for graces" as a slide: aslaris mant'd thes explaisid thas arranged Purcell's text, written on two lines - in one). In Hunter's later publication the same inexact information is found: "the single stroke is expressed as a slide, and indeed realization as a lower-note grace is occasionally suggested by fingering indications; support for Bevin's interpretation is provided in Prendcourt's treatise on harpsichord playing and thoroughbass $(c 1700)$ " [4, p. 712]. In the same article there follows a documentary unproven reasoning: "Although Bevin and Prendcourt may have identified one meaning of the single stroke, it is clear that the sign was also associated with upper-note realization." In Prendcourt's table nothing relates to the upper-note realization. Such a statement can only be made as a scientific assumption, but it must be shown on what official record it is based. Historical materials should be taken at "their face value" (H. Diack Johnston's wording concerning Purcell's "Rules for Graces"). 
a slide" [1, p. 146-7], and their recommendation was partially correct as will be seen lower, but the problem is too complicated to be solved unequivocally.

In attempting to obtain some more historically indisputable confirmation concerning the interpretation of virginal ornamentation in the first quarter of the $17^{\text {th }}$ century (and perhaps retrospectively some decades earlier), it is absolutely necessary, from our point of view, to pay due attention to the unique examples demonstrating the execution of ornaments in Edward Bevin's MS materials. They shed light on this complicated problem, but are not able to provide answers to all cases and to fit in all instances and all circumstances.

Among pieces for the organ and harpsichord by Blow, Tallis, Gibbons and other composers there are several written by Edward Bevin, and in one of them the author shows how (according to his understanding) some "Graces" written in the form of signs should be "exprest in notes" (Ex. 7).
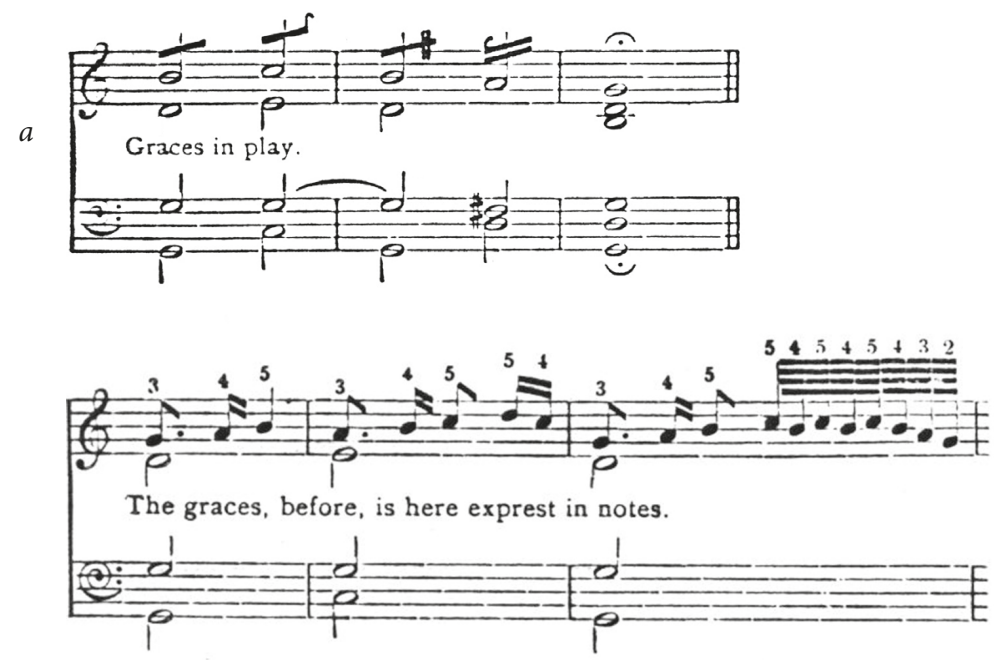

$b$

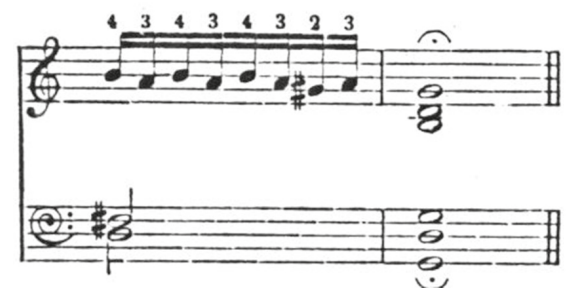

Example 7. Edward Bevin. "Graces in play", c1630. Examples are taken from the first edition of the monograph by Arnold Dolmetsch [17, p. 287-8]. They practically completely coincide with the ones cited by Dannreuther

9 The article "Sources" [18, p.38] provides the following information: "London, British Library, Add. 31403 (partly written by Edward Bevin, c1630). Music before 1660 occupies ff. 3-33; the remainder of the MS dates from $c 1700$. The earlier part contains music by both 'Edward Bevin' and 'Elway Bevin', the former being the son of the latter. Edward Bevin wrote also the Graces in play, followed by the same 'exprest in notes' on f. 5." In the Catalogue of the London British Museum, under No. Add. 31403, p. 5 (see: [29, p. 90]) it also states that the latest part of the paper dates back to 1700. Among the composers Hughes-Hughes names Blow, Tallis, Byrd, Elway and Edward Bevin, Blitheman, Bull, and Orlando Gibbons with several anonymous pieces. 
For a more accurate comprehension we have organized the ornaments from Bevin's "Graces" separately in the next example (Ex. 7.1) ${ }^{10}$.

$a$
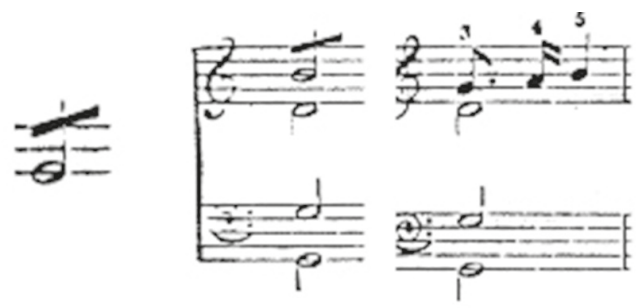

$b$

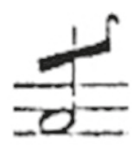

$c$
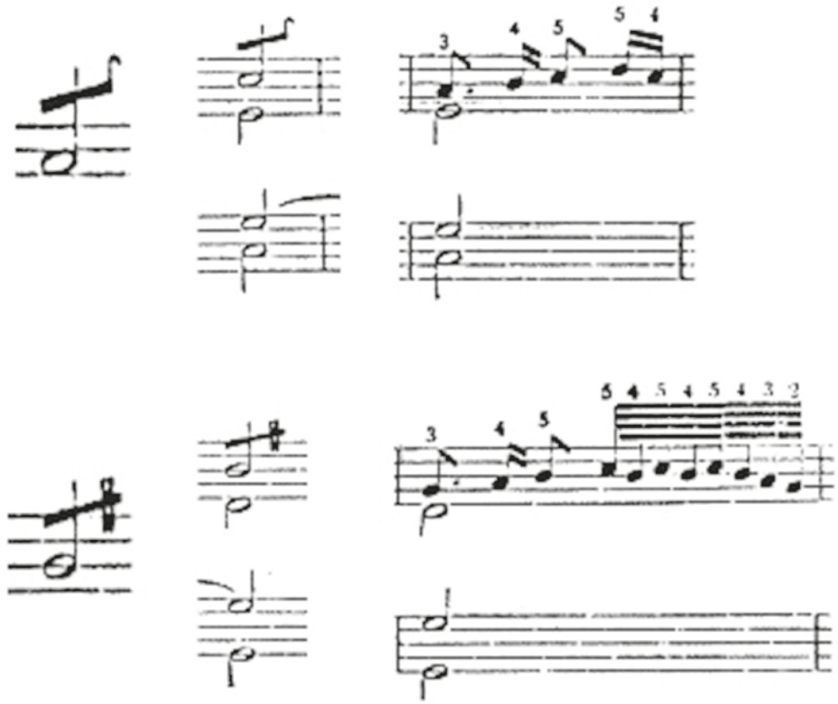

$d$
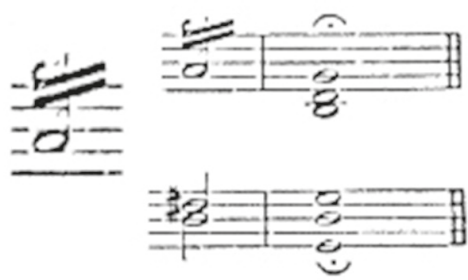

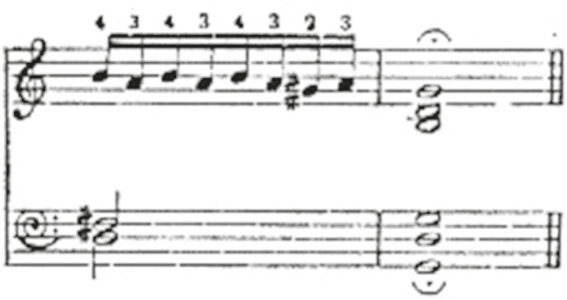

Example 7.1. Edward Bevin. "Graces in play", c1630 cited from the first edition (1915) of Dolmetsch's book

It is quite widely known that Bevin's "Graces in play" represent an "often cited table" [4], but unfortunately occurring in the scholarly works they are occasionally not accompanied with various inaccuracies. The first author to turn to Bevin's important materials was Dannreuther. However, his attribution of Bevin's MS is chronologically misleading,

10 The separate form of illustrating Bevin's ornaments is given in Ferguson's "Anthology" [2, p. 11]. However there are some minor discrepancies: the oblique lines should cross the stem of the notes, but not be placed above them, and in the example 7.1c the double stroke of this example should not be printed in oblique form. 
since Dannreuther states that the "older portion of which [i. e. the MS] appears to date circa 1680, contains the following signs for graces, and their explanations, which from the position they occupy in the book may be assigned to that date" [16, p. 25]. This dating moves the manuscript material almost 50 years later, that is, to another stylistic era (the era of Chr. Simpson, J. Playford, M. Locke, Th. Mace, and the young Henry Purcell). ${ }^{11}$ The examples from Bevin are cited by Dannreuther in full, and the author refers to them to confirm his previous suggestion that "the simple stroke in Parthenia [...] sometimes stands for a slide of a third upwards" [16, p.26].

Dolmetsch attributes the material "circa 1600." It should be noticed that Bevin's "Graces" are incorporated by Dolmetsch in the Chapter of "Position and Fingering." It is more likely that Dolmetsch worked directly with the MS, because he remarks "in a blank space [in the MS], the following bars of music have been written... [and further:] although no precise date can be ascribed to it" [17, p.287]. This would mean that the material in Dolmetsch's book must be analogous to the MS source.

Ferguson holds a different opinion, believing that Bevin's MS was "late in date and of uncertain relevance" (authors' underlining. - A.P., I.R.) and "is ascribed to the composer Edward Bevin in British Museum Add. MS 31,403, of c. 1680-1700." Here the date is also given some fifty years later. Pollack's view is uncertain since only a general dating of the MS with Bevin's "Graces in play" is proposed: "dated sometime between c. 1635-1700" [13, p.249].

Alan Brown in the Chapter "Performance Practice" has only the following to say about Bevin's material on the realization of the single stroke, i. e. that some support for the slide played from the third below is "in Edward Bevin's tiny piece 'Graces in play' dating from c. 1630" [6, p. 49]. Bevin's small table named "Graces in play" being historically extremely important evidence, since it was the first displayed in England, is not even cited in Brown's solidly based and very informative work. Hunter for his part cites Bevin's table [4, p. 712], but verbally explains just the single-stroke grace expressed as a slide.

It should constantly be considered that Bevin's "Graces in Play," written in the early seventeenth century, primarily display his personal judgment, as in many other authors ornament recommendations too, but it was also impossible for him to avoid reflecting the general opinion prevailing at that time or (in certain cases) some other impact borrowed from another national culture. More than likely Bevin's graces "exprest in notes" may in retrospective be related to the ornamental practice of the previous decades. Each sign and its interpretation must be carefully considered.

The single-stroke ornament. Thus, as discussed above, the single-stroke ornament sign

in Bevin's "Graces in play" expresses the slide in a dotted pattern:

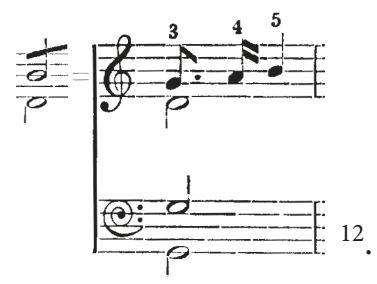

11 The same date is found in the book published by Beyschlag specially designed to the performance of ornaments [30, p. 52].

12 The fingering is original. Our copies are from Dolmetsch's new edition of his work [17, p. 387-8]. 
This manner of performing the slide as a dotted figure is rarely mentioned by scholars ${ }^{13}$. In Purcell's "Rules for graces," the "slur" (i. e. the slide) is performed smoothly in the rhythmic sense similar to the "Elevation" in Christopher Simpson's table (1659). In the distant future, this manner of executing slides as a dotted figures was recommended by C.P.E. Bach in 1753.

The single-stroke ornament with a turn / appoggiatura from above. Next Bevin shows that the single stroke may not only be performed dotted, but also may have a specific end-

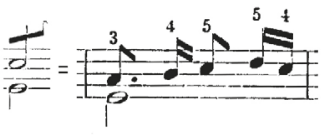

ing (a turn or, to be more accurate, an appoggiatura from above:

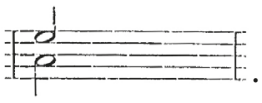

Such a manner of performing a single-stroke ornament is rarely discussed as well.

The trill (shake). According to our point of view, one must pay special attention to the fact that the trill (shake) is unquestionably marked by a double stroke and definitely performed in Bevin's interpretation beginning with the upper auxiliary note. This is very important as it marks the onset of a new period in the performance of trills. But it is necessary to take into account a very specific feature in Bevin's execution of this trill, namely, the trill-ending. Is it possible to equate two species of trills: the ones with trills without specific trill endings, and those with one? Another question arises: could it possibly (retrospectively) mean that such double strokes may be, or should be, performed at the beginning of the oscillation from the note above and be played without a cadential turn in early virginal music? In Bevin's examples there is no separate double-stroke ornament sign without any additions to it! In other words, is it permissible to conclude that trills without cadential turns may be performed beginning on the upper auxiliary note in virginal music: or to be more precise, in the form of a short four-note trill ( itive answer to this question based on incomplete information would be questionable.

One should note that in the context with the slide the double-stroke is marked verti-

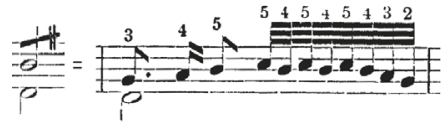

cally crossing the single oblique stroke:

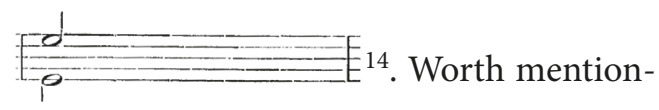

13 A similar pattern occurs in Prætorius's treatise, but in the latter the example is given not in the form

of a chord of a third, but in a successive movement of a third upward:

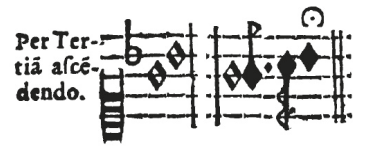

p. 234]. However it shows that such a rhythmic solution definitely existed. Here it must be noticed that the diminution is realized on the beat.

${ }^{14}$ In Ferguson's "Anthology" [2, p. 11, example No. 5] these double strokes are typed oblique. It has been noted above that according to a rhythmically correct execution hemidemisemiquavers must be written but not demisemiquavers. 
ing is the stepwise figure at the end of the trill, which through a move to a third in the next part of the same bar (in the unrealized example) connects it with the beginning of a cadential trill accompanied by a turn (not in two bars as is seen in the example above taken from Dolmetsch's book; the same placement of notes is given in many other publications too). Such patterns, being written in one measure as one compound ornament, are often seen in the music of that period (see lower).

The trill (shake) with a cadential ending (turn). Further, in the context of the double oblique stroke with a sign for a turn the former definitely designates a trill (shake) begin-

ning on the beat from the upper auxiliary note:

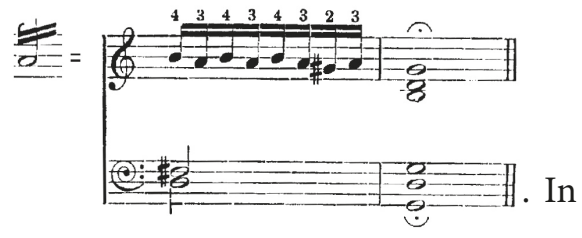

Bevin's realization it represents the very often written out cadential trills which are in infinite numbers of occasions found in the music of the $16^{\text {th }}$ and $17^{\text {th }}$ centuries, but which are not marked by any special signs. The turn in Bevin's example (strangely) is placed not in the end of the double oblique stroke sign, alike the single-stroke ornament with an ending appoggiatura, but in its beginning. As an example of a written out ornamental figure, we can cite a similar classic version from the "Fantasy" by Byrd [25, vol. I, p. 41]

where the cadential trill begins after a third from below:

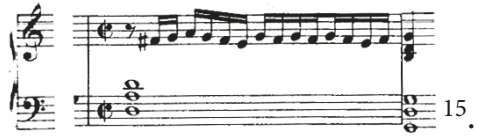

If the example from Bevin was recorded correctly (consisting of two minims in a bar: see. Ex. 7) then the realization should not have been split into two bars with one minim in

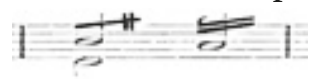

a bar. Thus, the second measure ( measures with one minim in the bar. It is important that in the measure with two minims in a bar the realization of the ornaments would receive the next form:

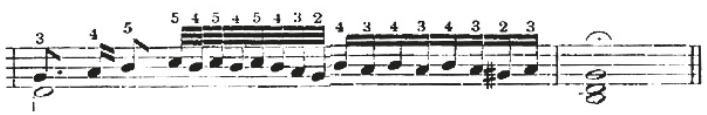

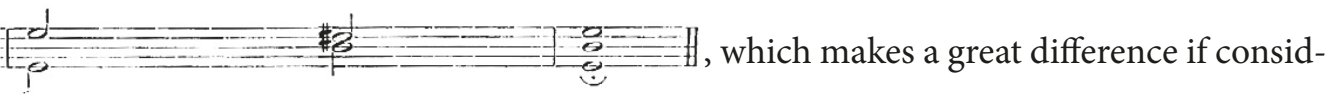
ered in comparison as two separate bars with two separate ornament signs. The trilled part in Bevin's execution matches almost exactly with the cadential trill-end in Andrea Gabrielli's sixth Canzona titled "Canzon Francese detta Orsus" [32, p. 25]:

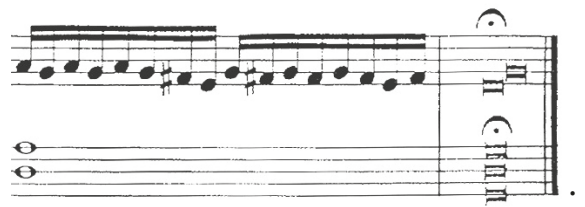

${ }^{15}$ In the edition by J. A. Fuller Maitland and Barkley Squire [25] these notes are written on two lines. We arranged them in one. 
The most essential difference, however, is that Bevin marked the ornaments in his Graces to play with certain special signs, while in Italy (Gabrieli, Frescobaldi and other composers) the ornaments were written out in notes in the form of diminutive figures.

Lastly, all arguments will become historically valid and will become legitimate only when scholars will have at their disposal versions of the original MS documents of Add. 31403, but not their transposed copies in modern notation.

Apart from the fact that the music of the virginalists was in many ways unique in comparison with the compositions for keyboard instruments of Italy and Germany, and still more distinctive was the marking of ornaments (especially from around 1560-1570), but cadential and semi / quasi-cadential trills (shakes) written-out in notes with trill endings in virginal music as in Byrd's pieces, or in Bevin's Graces were widely known in Italy and Germany. The problem stands of whether in that period diminutive written-out shake patterns, beginning from the upper note without a cadential ending, were used.

Marin Mersenne demonstrated in his magnificent "Harmonie Universelle" [33, p. 355] ${ }^{16}$ a somewhat similar trill ("tremblement"), which is at first glance without the conventional cadential ending, but instead it has an anticipatory ending. Most noteworthy is the fact that the realization begins from the upper auxiliary note and metrically distinctly starts on a beat (Ex. 8).

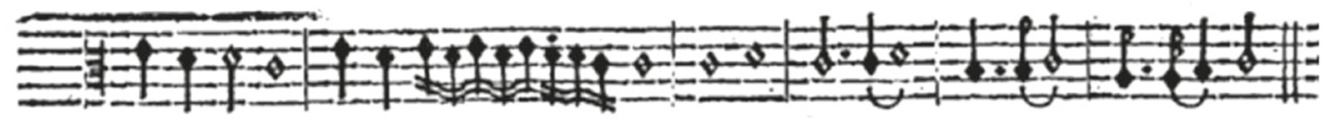

Example 8. Mersenne M. Seconde Partie de L'Harmonie Universelle, Livre Sixiesme, 1637 [33, p. 355] ${ }^{17}$. The example is given in $\mathrm{C}$ (tenor) clef

There would be no problem in understanding Mersenn's example with the realization of the tremblement if there were no dot above the note "d." For a correct understanding of the method of executing this ornament Mersenne accompanied the example with a text in which he tried to provide a coherent explanation that made sense to him of the marked dot: "Et si son veut faire cette cadence auec toute sa perfection, il faut encore redoubler la cadence sur la note marquée d'vn point dessus, auec vne telle delicatesse, que ce redoublement soit accompagné d'vn adoucissement extraordinaire, qui cótienne les plus grands charmes du Chant propose"18. Most possibly, Mersenne knew exactly what he meant with the words "il faut encore redoubler la cadence sur la note marquée d'vn point dessus."

${ }^{16}$ Neumann [34, p. 244] erroneously gives the date as "1636." Unfortunately in both volumes of Mersenn's "Harmonie Universelle" (1636 and 1637) there are different kinds of mistakes (for such an enormous size of the two books - it is understandable, but to the readers and especially to scholars it presents tangible difficulties in working with his treatises). Some of them the author explains and amends in the end of chapters and "Books" in "volumes." In our case following p. 332 is p. 133, and after that from p. 140 comes p. 341,342 etc.

17 Before the notated text in Mersenn's treatise there is an explanation where it says: "For example, if the cadence [melodic cadentional ending or the conclusion of a phrase/melodic structure] consists of 3 notes $l a, s o l, f a$ [and] the trill [tremblement] should be made on sol by making $4,8,16$, or as many times as one can, or as we want [thus] la, sol, la, sol, la, sol, etc. as is seen in the following example..."

18 In Robert Forston Williams's dissertation the translation is as follows: "If we wish to form this cadence in all its perfection, we must again redouble the cadence upon the note indicated with a dot above, with such a delicacy that this redoubling is accompanied with an extraordinary softening, which contains the greatest charms of the song proposed" [35, p. 782]. 
However this explanation does not contain an adequate understanding for the modern reader, on the contrary, everything becomes more complicated. This is why in Williams's translation there is no attempt to clarify the meaning of Mersenn's explanation.

Mersenn's example, and the accompanying explanation, had already attracted the attention of Max Kuhn in 1902. In Kuhn's opinion "the note-example had not been accordingly [literally: happily] chosen", and perhaps "in the following [example] it will be better understood" [36, p. 81]. The provided example (Ex. 9) has a turn (cadential ending) added to the ornament, but completely distorts Mersenne's main principle: the beginning of the tremblement on the upper note.

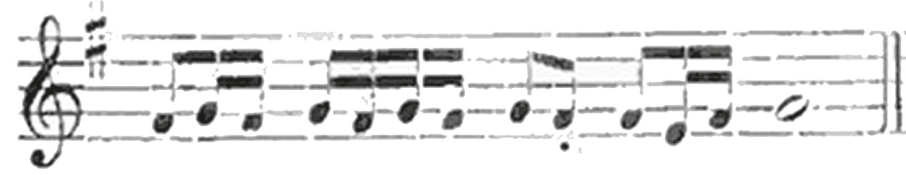

Example 9. M. Kuhn. Die Verzierungs-Kunst in der Gesangs-Musik des 16.-17. Jahrhunderts [36, S. 81]

The idea of adding a turn to the trill ending comes from the understanding of Mersenne's words "to redouble the cadence" because Mersenne might have treated the term "redouble" in the meaning "turn" which was used in his time, and it is the "turn" which adds "perfection" and the "greatest charm."

Fr. Neumann for his part in an attempt to circumvent the difficult-to-understand Mersenne's recommendation, replaces the word "cadence" in the latter's text with the word "notes." Thus, in Neumann's translation Mersenne's text reads: "in all perfection, one must double the note that has a dot on top" [34, p. 244-5].

Logically speaking, by means of a cadencial ending, Mersenne's explanation is seen primarily as an attempt to smooth out the not quite appropriate reiteration of the sounds at the end of the melodic line. In other words, he suggests starting the trill with the upper auxiliary note, but adding a cadential turn to it. This brings us directly to the realization of shakes marked by Bevin as oblique double strokes.

On the one hand, some scholars try to use any historical material to prove that short shakes in virginal music should first of all be performed in the four-note pattern beginning from the upper auxiliary note. On the other hand, after commenting on Mersenne's example Neumann attempts further to show that the French musician contradicts himself, and returns to the manner of performing the tremblements beginning from the main note. At first glance, it seems that Neumann's reasoning, confirmed by musical examples, is coherent and the idea is well founded, but he did not notice that in his reasoning one concept is substituted by another, i. e. that the practice of executing a note to be trilled equates the diminution practice. Something analogous was shown earlier in the reasoning relating to the examples from "Graces in play" (Bevin), when a trill with a cadence conclusion was equated with a simple trill beginning with an upper auxiliary note and without any cadential ending.

Returning to Mersenne in one occasion, the author explains how the tremblement should be performed / resolved and in the other case he shows how to employ diminution-formulas to embellish the original text which attracted Neumann's attention. A diminution passage is in no way a resolution or an execution of a written main note marked 
with an ornament sign; it is a melodic figure which replaces longer notes by those which are shorter in value. ${ }^{19}$ Neumann had not noticed it and wrote: "It is interesting and very revealing to put Mersenne's trill model (and implicitly those that were to follow) into the right perspective by comparing with an illustration of diminutions in which all trills are written out. In this illustration almost all of the trills start not with an upper note but with a somewhat sustained main note on the beat" [34, p. 245] (authors' underlining. A. P. and I.R.). As an example to show what it is about, just one diminution pattern from Mersenne should be sufficient. Mersenne [33, Livre Quatriesme, p. 186] cites Henry Jehan le Jeune's Fantasie à 5, and lower exhibits a diminution version. In Ex. $10^{20}$ only the beginnings of the Fantasie are provided.

a

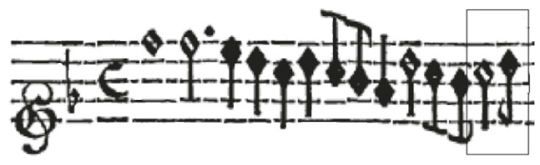

D I M I N V T I O N.

$b$

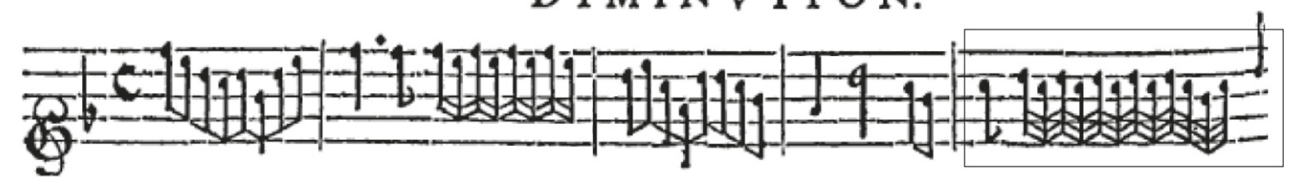

Example 10. The first line shows the beginning of Henry Jehan le Jeune's Fantasie (the third part) and the lower line shows a Mersenne's diminution version. The parts taken by us in frames represent in Neumann's point of view how to resolve the trill on the note " $a$ " with "a somewhat sustained main note on the beat"

In the discussion of the diminution part in Mersenne's examples Neumann does not stress the point that a shake beginning from the note above is shown in the second measure. The author of the monography on ornamentation even omits mentioning this part of Mersenne's example. According to Neumann's reasoning, the resolution should have been

next:

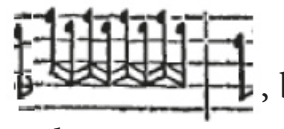
, but in Mersenne's original there is no "stop" on the main note in his first diminution example: the tremblement on the note 'e' begins exactly on the upper auxiliary note ' $\mathrm{f}$ ', thus, repeating the previous crotchet/quarter-note ' $\mathrm{f}$ ':

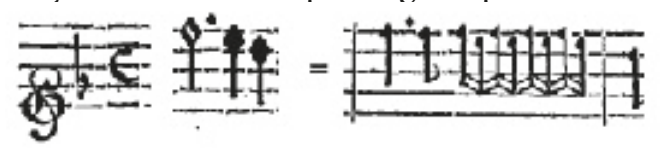

[33, Livre Quatriesme, p. 186, 188].

Diminution patterns which Neumann presents as trills starting not on an upper note, but with a sustained main note were used as a cliché practically by all musicians in their examples with diminutions at the end of cadences or semi-cadence structures. They play an important part, for example, in the music published by Attaingnant in 1530 [37, p.7].

19 Cf. "Diminution" in the New Grove Dictionary (2001).

20 The first part of Henry le Jeune's Fantasie à 5 is written in notation without bar-lines. The "Diminutions" are shown by Mersenne in the c measure divided into bars. 


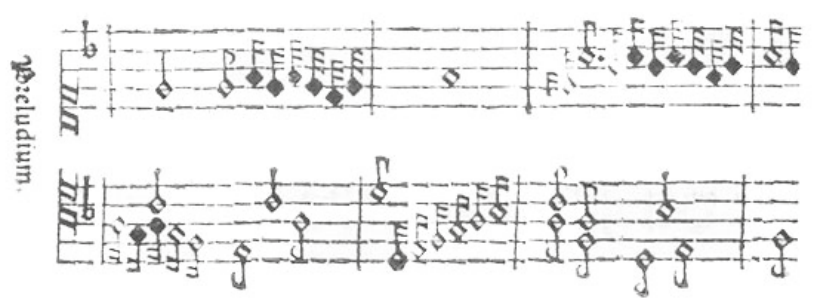

Or in Giovanni Luca Conforti’s "Breve et facile maniera" [38], cited from [39, p. 238, Ex. 87]:

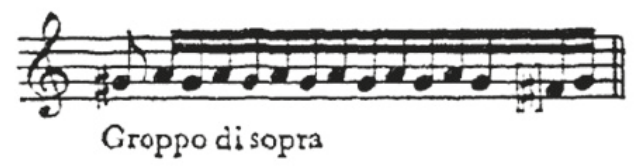

In Frescobaldi's Toccatas and Canzonas (Ex. 11).

Most convincing is the first example from Diruta's Il Transilvano [42, p. 18-9; 43, p.66] where the author shows how the "Groppi di Accadentia" should be performed (see the next original and its transcription into modern notation):

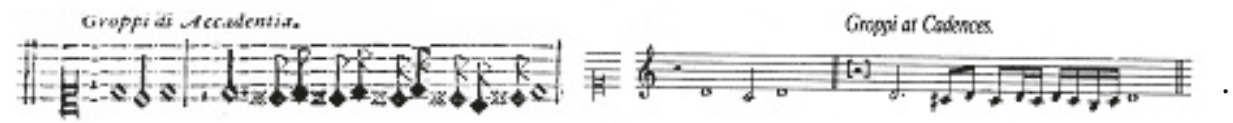

The same patterns with a stop on the main note before the repetitions of the two adjacent notes make up an important structural and musical part in the third variation of F. Richardson's Galiarda in the Fitzwilliam virginal Book [25, vol. I, p. 33]:
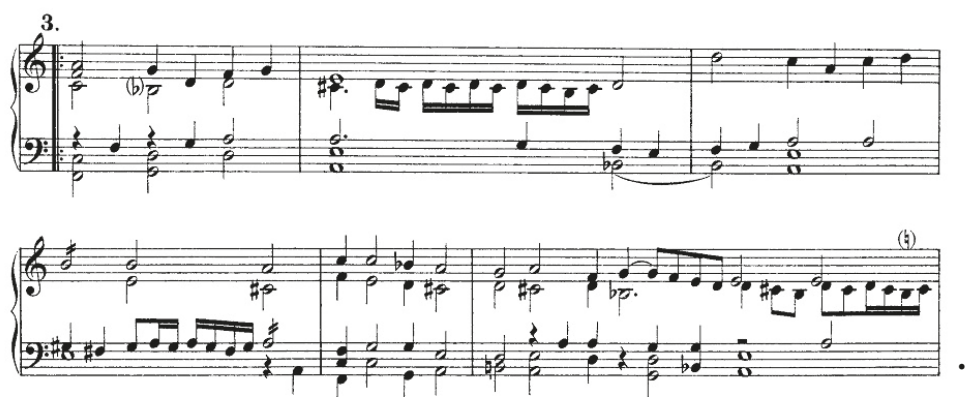

Among the virginalists, Richardson especially preferred these diminutions (see: Galiarda. Fitzwilliam Virginal Book [25, vol. I, p. 93, No. XXIX]).

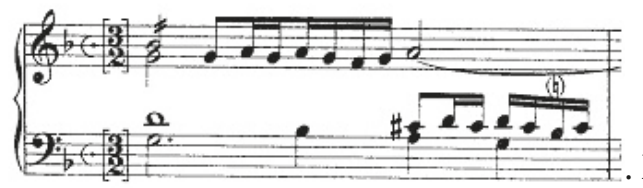

Even in the fifteenth century Johannes de Florentia ended the phrases in the Madrigal (c1360) with such cadential diminution figures (see [30, p. 8]).

The numerous examples shown above do not testify, as Neumann states, that "almost all of the trills [in Mersenne's example] start not with an upper note but with a somewhat sustained main note on the beat" (our underlining. - A.P., I. R.). On the contrary they 

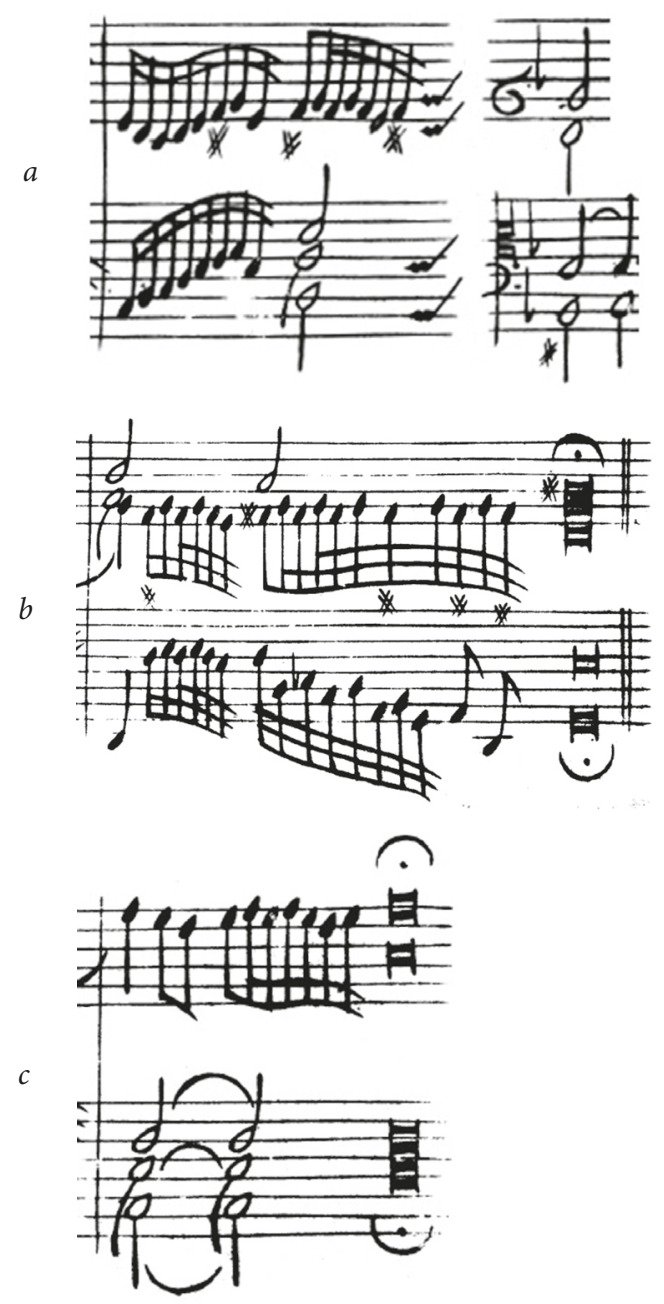

Example 11. Frescobaldi [40, (a) p. 2, m. 39 and (b) p. 3 - last bar] and (c) end of the Canzona Quarta in F [41, p. 55] last bar (c)

testify irrefutably that namely Mersene's cadential patterns, which Neumann cited, start in accordance with the then established tradition of a main-note stop at the beginning of the diminution, but the latter are by no means executions of trills.

Hunter points to the fact that much earlier than Mersennne, Thomas de Sancta Maria (1565) showed genuine interest in the new manner of performing trills (redobles) beginning them from the upper auxiliary note which, however, should be played before the beat, thus in an anticipatory manner. See in Ex. 12 the interpretation of ornaments with the prescription "nuevo". Hunter gives a fine condensed summary of de Sancta Maria's main ornaments (Ex. 12) $[4, \text { p. } 710]^{21}$ :

${ }^{21}$ The "nuevo" examples are not printed in de Sancta Maria's treatise. However there are important and vivid explanations of this "new" manner of performing ornaments by de Sancta Maria: "A current usage that one should note well because of its great artistry, is to begin the redoble or the reiterated minim quiebro on the note above that on which it is concluded; furthermore the first note of this redoble or quiebro must be 


\section{REDOBLES}

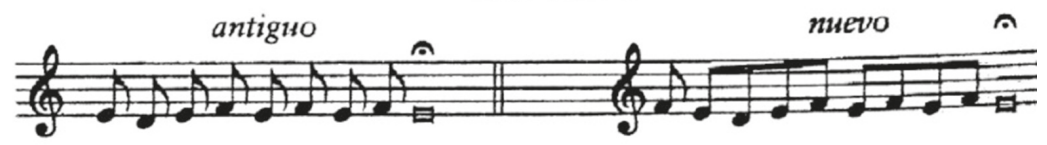

QUIEBROS
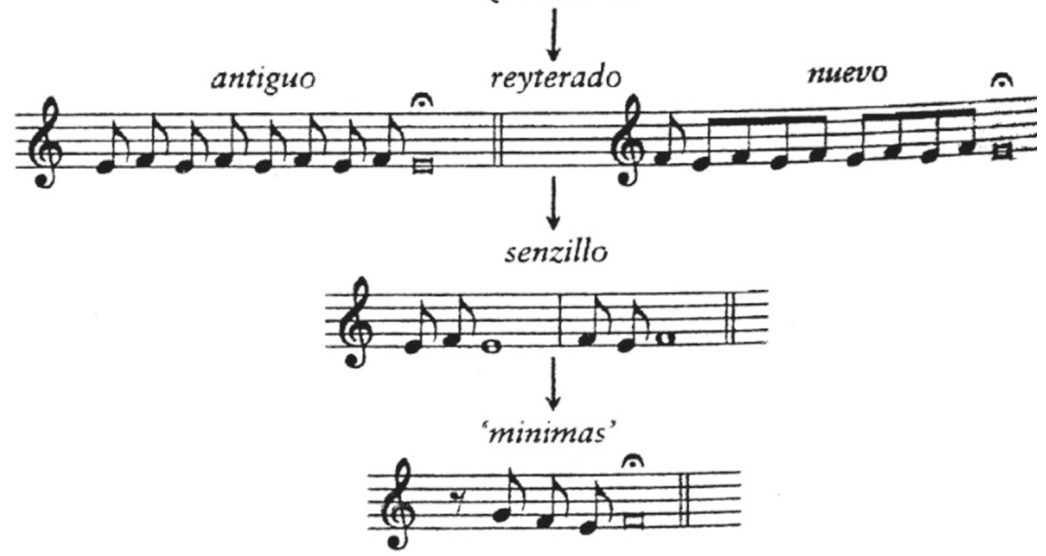

Example 12. Hunter [4, p. 710]. Interpretation of ornaments from Sancta Maria's, Libra Llamado El Arte de Taner Fantasia, 1565, organized by Hunter in the form of a table 22

The beginnings of the trills (on the beat or before it) constitute the basic difference between de Sancta Maria's interpretation of a "nuevo" trill and Mersenn's. Further, there is absolutely no certainty in where and in whose performing school such a manner of interpretation of the beginning of the trill had been used, because de Sancta Maria tells us only that there had been "a current usage" which should be noted by musicians. According to contemporary knowledge such a manner of performing trills which anticipate the beat is nowhere else explained in the sources beginning from de Sancta Maria and till the $18^{\text {th }}$ century ${ }^{23}$.

struck alone and the second note must be struck with the chord then occurring" and next: "These types of redoble and quiebro, and the other type of minim quiebro formed with a combination of tone and semitone, are very new and very elegant, and they produce so much grace and sonority (melodia) in the music, and heighten it to such a degree and with such satisfaction to the ear, that it seems quite a different thing from that played without them. Quite rightfully, therefore, one should always use these and not the others, which now are antiquated and wanting in grace" [44, p. 126, 127].

${ }^{22}$ It must be repeated once again that de Sancta Maria's Libra Llamado El Arte de Taner Fantasia had practically no circulation not only in his own country but also abroad. If it would have even a minimal circulation then the performers on keyboard instruments more than a century earlier would use the first (big) finger in stepwise passages (scales) because such fingerings are given in his treatise. For example, de Sancta Maria (along with the so called "old" fingering) recommends the next ones: 6 (a) are especially innovative.

${ }^{23}$ Nevertheless Frederick Neumann tries to draw attention to this performance version as if it had a wider distribution, when he emphasizes that "It is very interesting and probably very significant, too, that the emerging convention of starting the trill with the auxiliary is linked to its anticipation." But on the next page the prominent scientist contradicts himself when he comments on Mersenn's execution of the 
In Italy thirty-five years later (1600) Emilio del Cavalieri (in one of the first ever published ornament tables; however, very short consisting of four ornaments) begins the cadential and the ordinary trill ("groppolo" and "trillo") from the main note (Ex. 13), thus according to the traditional stylistics of that and earlier periods.

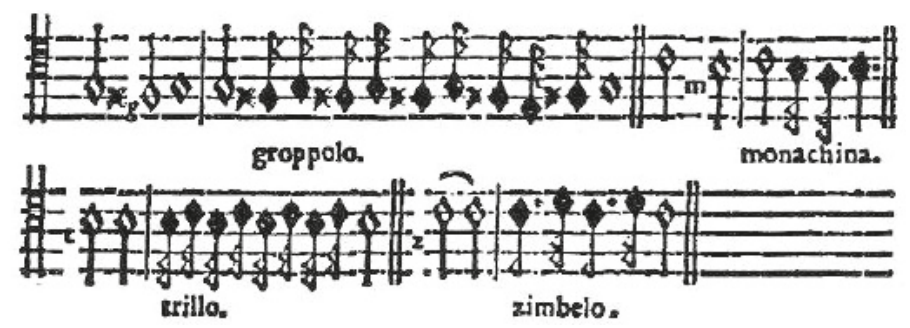

Example 13. Cavalieri, 1600 [45]

It would be uncomplicated if there were no other Italian materials and no other opinion. In her study dedicated to Parthenia, Janet Pollack [13, p. 249] directs her attention to the materials from the famous Italian treatise Il Transilvano (1593) published by Girolamo Diruta and to the Spanish treatise by Tomas de Sancta Maria (Libro llamado Arte de tañer Fantasia). However, it is hard to make sense of Pollack's recommendations because they consist of mutually opposed statements. In relation to Bevin it says, "the double stroke is a shake (trill) approached from above the written note whether in a rising passage or descending." Then this idea contradicts the recommendations in both treatises named above, and Pollack states that the authors (Diruta and de Sancta Maria) "suggest trills beginning on the written note." Directly in the next sentence Pollack infers: " $<\ldots>$ from these sources one can conclude that the shake may begin either on the written note, or the auxiliary note $\langle\ldots\rangle$." Suddenly the following summarization is drawn: "However, Byrd with his written-out ornaments in Parthenia makes clear that the earlier repertory expected the double-stroke ornament to begin on the auxiliary note"24. In result we learn that the execution of the double stroke "may also depend on the musical context, although beginning on the upper auxiliary note appears to be preferred."

It is necessary, firstly, to specifically repeat that in Bevin's examples and in Byrd's "written-out ornaments in Panhenia," the shakes are cadential ones having a written out suffix (or in other words: a cadential or semi-cadential ending). So far a four-note written out shake ( or in any other of it's rhythmical solution) was not found in

trill saying that "the metrical start of the trill with the upper auxiliary on the beat became almost standard practice for keyboard ornament tables in the 150 years to come" [34, p. 244, 245].

${ }^{24}$ Written-out cadential ornaments as a stylistic cliché were in all European countries. It is not clear what connection could be between Byrd's virginal music and Diruta's Il Transilvano because the latter had been published in 1593, and certainly no connection with Thomas de Sancta Maria's treatise the editions which represent a historical rarity. It only began to be mentioned in the late end of the $19^{\text {th }}$ century and the translation of some parts were published in 1910 by Otto Kinkeldey. During the early period de Sancta Maria's treatise was referred very infrequently. RISM names only eight libraries with collections which have these unique publications, not counting the Scholarly Library of St. Petersburg State Conservatory, which possesses an original edition from 1565. And most important is that the music of the virginalists, exepting their contrapunctal works, has practically little in common with the keyboard music of French, German, Italian or Spanish composers. In none of these countries can one find such elaborately ornamented with special signs compositions as in England of the Golden Age of the Elizabethan epoch. 
virginal music of that period. Thus, the cadential and upper or main-note shakes must be clearly differentiated. Secondly, probably the only case, which may be found where there is such, an example with a four-note written out shake is in Diruta's Il Transilvano (paragraph on "Modo di far li tremoli") in the part where "Essempio di tremoletti, sopra Crome" are shown (Ex. 14). Diruta's Transilvanian accompanies the musical example with a verbal explanation: "Transylvanian. <...> in the second example (see: Ex. 14), I find the same thing, namely that the tremoletto of four biscromes falls on a bad note, and the second tremoletto falls on a good note.

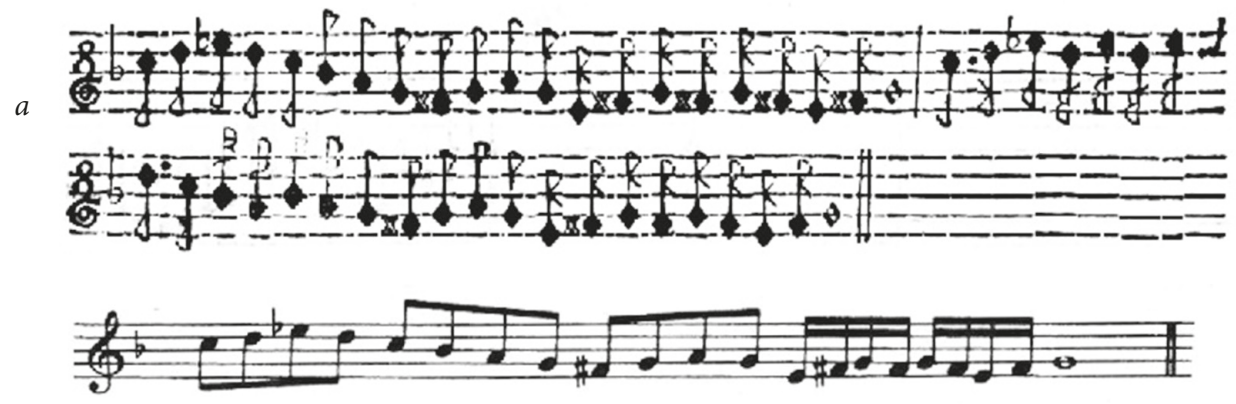

$b$

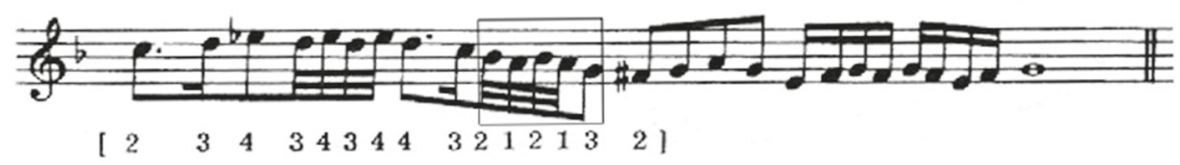

Example 14. Diruta, Il Transilvano [42, p. 19] (upper example "a"). Into modern notation it is transcribed in the English translation [43, p. 71] (in the lower example "b" the part taken in a frame is by the authors of this paper, the numbers in brackets with the proposed fingering are recommended by Soehnlen in accordance with the requirements of Diruta) $)^{25}$

The reasoning above concerning the cadential form of shakes in Bevin's examples and the cited sources is insufficient to unambiguously establish that beginning the shakes on the upper auxiliary note in virginal music "appears to be preferred" 26 . In summary form

25 The part on ornamentation in Diruta's work has been studied in 1893 (exactly 300 years after its publication) in the work by Dannreuther with the next comment to the above cited examples: "His groppi exhibit shakes which start with the upper accessory and not with the main note as he demands. This ambiguity in Diruta is representative of the vexatious question whether shakes shall start with the accessory or with the main note which persists to the present day. Here, as already stated, it is case law, if there is to be any law at all" [see: 16].

26 This also concerns Brown's statement that "in the last decades of the seventeenth century, the double-stroke sign was adopted for the 'shake' (upper-note trill without termination)" and further: "The short upper-note trill (b) [ his point of view, Brown refers to the opinion expressed in the work published in 1969 by Curtis: "Alan Curtis has observed 'it is inconceivable that this most basic of ornaments, present throughout the history of the literature for harpsichord and related instruments, should not have been used by the Virginalists' (Curtis 1969, 209-10)" [6, p. 49]. Ferguson's classification may be added here: "(a) shakes with, and starting on, the note above (this is the most usual)..." ([2, p. 12]; authors' underlining. - A. P., I. R.). On the previous pages it has been shown that "most of the basic" ornaments were not the ones which started on the upper auxiliary note, but on the main one. 
the most noticeable examples from Diruta demonstrate the main-note beginnings of the "Groppi" (Ex. 15) or (Ex. 16).

\section{Groppi at Cadences.}

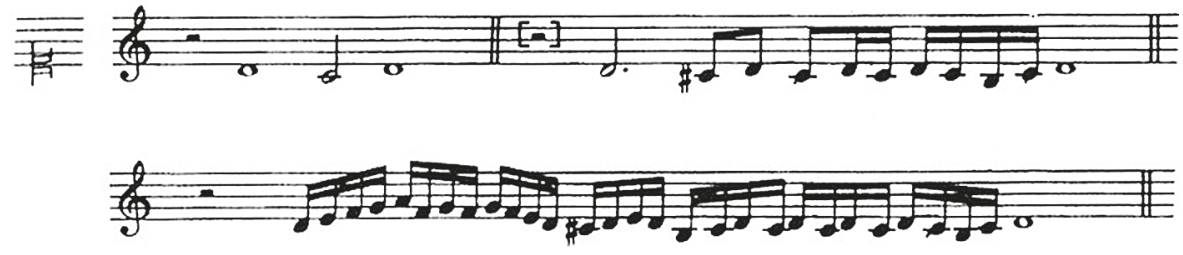

Example 15. Diruta, "Il Transilvano"; cited from: [43, p. 66]
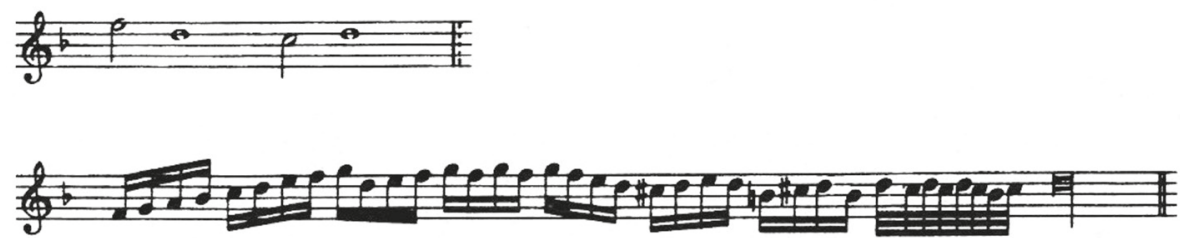

Example 16. Diruta, "Il Transilvano"; cited from: [43, p. 67]

Diruta: "Tremoli" (trills beginning from the main note) at minims and at crotchets (Ex. 17).
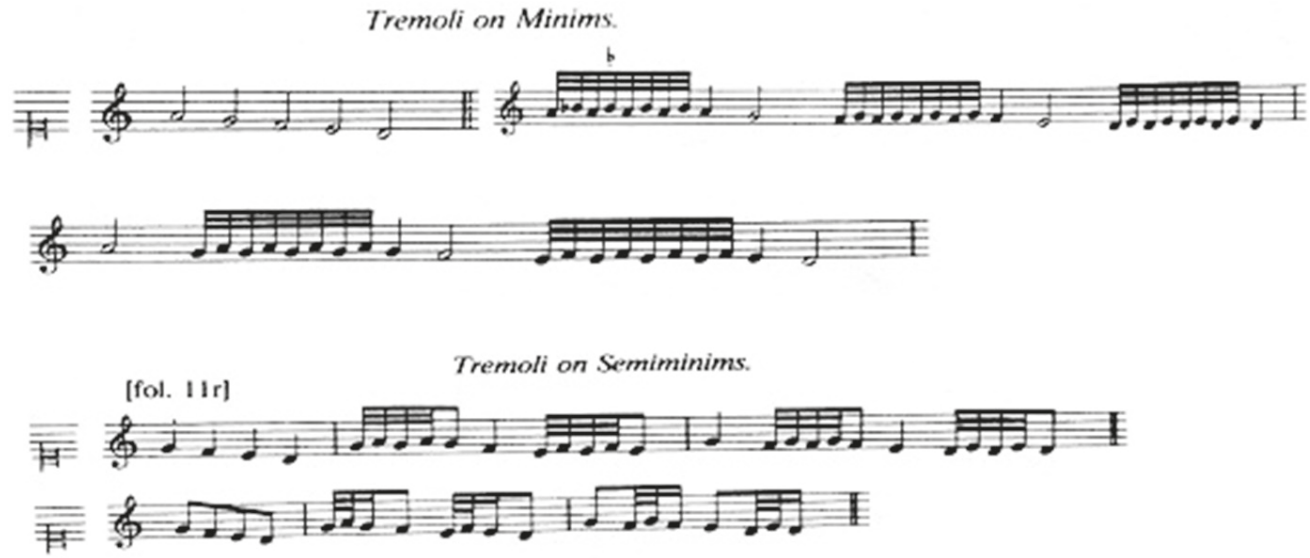

Example 17. Diruta, "Il Transilvano"; cited from: [43, p. 69]

Diruta: "Tremoli" at quavers. These examples require special attention, as they indicate the existence of three-note ornaments (shortest pattern of a trill) in the form of the inversion of a later French pincé (Ex. 18).

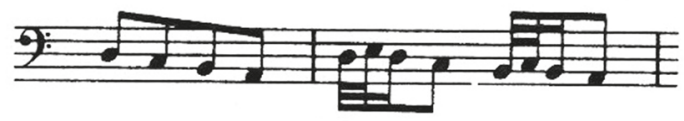

Example 18. Diruta, "Il Transilvano"; cited from: $[43$, p. 70$]$ 
Prætorius [31, p. 232-40] recommends practically the same execution of ornaments in teaching singers the Italian manner (Ex. 19) with the single exception compared to Diruta where the latter (also as an exception) has the four-note short trill (see: Ex. 14). It is important to mention that the ornaments in the recommendations of both authors do not have special signs for marking the diminution ornaments. If these diminution formulas would be marked then they would automatically shift to the category of graces.

$a$

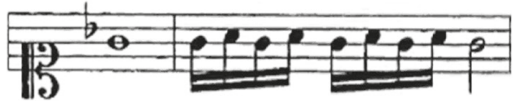

$b$
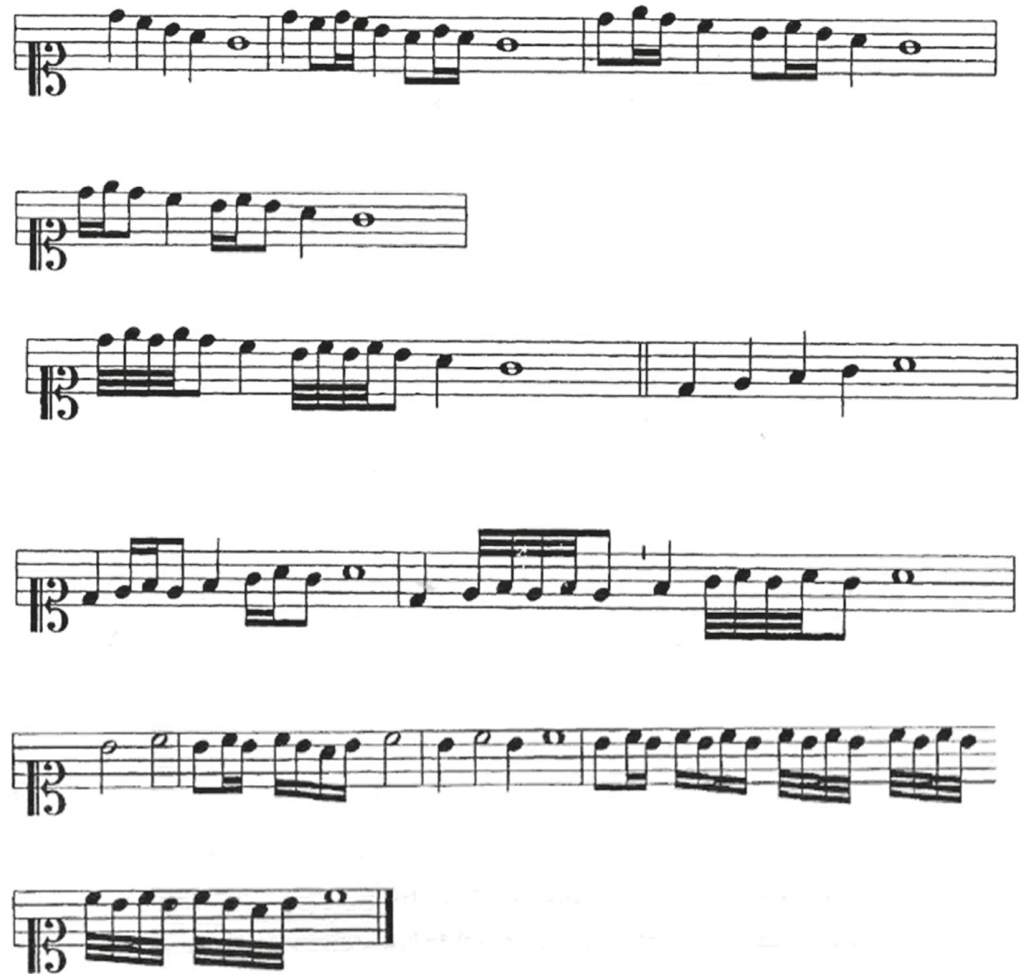

Example 19. Prætorius, Syntagmatis Musici, Tomus Tertius.

a. Ascending and descending Tremoli ${ }^{27}[31$, p. 235]

b. Tremoletti ${ }^{28}[31$, p. 235]

c. Groppi [31, p. 236].

It is not difficult to draw a parallel between the above shown Spanish, Italian and German (in fact - also Italian) explanations of the manner of executing ornamental dim-

27 Prætorius writes lower that "these ones are more appropriate for organs and instruments with quills than for the voice".

28 Prætorius points out that "the organists name them as Mordanten or Moderanten". 
inutions with the recommendations which scholars offer for the performance of English virginal signs of ornamentation and found in the "Graces in play" proposed by Edward Bevin. Except the pre-beat execution and the four-note performance of the shake, all ornament interpretations match. The four-note execution of the double-stroke virginal ornament sign, even taking into account the fact that we are accustomed to it when performing French clavecin music, stylistically is a foreign type of a Grace if used in English virginal music in the period $c 1540-1640$. However in all cases where there is a cadential or quasi-cadential musical structure accompanied by a double-stroke ornament sign in the music of the virginalists the historical material confirms the necessity of beginning the shake from the upper auxiliary note, and mostly with a cadential turn / suffix.

There is another important issue in scientific literature connected with the possibilities of finding answers to the execution of virginal ornaments. It concerns the fingering markings in the music of the virginalists. The original finger indications written in some sources in the context with grace signs might, as Hunter states, "offer some help in determining appropriate realization of the implied graces" [4, p. 171]. Examples of such combined indications are found in many MS. A passage in Res. 1186 is of special interest in detecting possible solutions for the execution of the single- and double-stroke ornaments, in this certain case in the left hand (Ex. 20). Here the single-stroke ornament - from our point of view - can be historically and musically realized in three ways: much more likely as an appoggiatura from below, i. e. "fore fall" (first line of fingering which shows the notes to play), as a mordent (second fingering) and less likely as an appoggiatura from above/ "back-fall" (the lowest fingering). The double-stroke shake may hardly be performed as a four-note ornament (hecause both the rather fast movement does not allow it, and also it would demand a repeat of the second finger. Thus a fingering for a three-note grace, if preferred here.

This has been just one of a great number of occasions where the performance of ornaments is linked with the original finger marking. However even in this field of research of numerous early sources (printed and in MS), the results may only help in finding an adequate solution, but are not able to provide extensive and unequivocal answers to the question of performing virginal ornamentation.

The problem of executing virginal ornaments of the Elizabethan period and three decades of the later years, as well as the study of all inexhaustible early and modern literature on this topic cannot even to some extent be adequately presented in an article. The authors of the present work have tried to show that in the historical evidence the short trills, marked by double oblique strokes, should have been predominantly performed, starting not with the auxiliary note. A start on the upper auxiliary note, if it is not in a cadential context, in the execution of short trills is stylistically not justified. This manner of performing such short (and not only short) trills from the upper auxiliary note came into existence a few decades later (c. from 1650).

\section{References}

1. Borren van den, Charles. The Sources of Keyboard Music in England, <...> Transl. by James E. Matthew. London: Novello \& Co., [1914].

2. Ferguson, Howard, ed. Early English Keyboard Music. An Anthology. 2 vols. London; New York; Toronto: Oxford University Press, 1971, vol. I. 
3. Hunter, Desmont. "My Ladye Nevells Booke and the Art of Gracing". In Byrd Studies, ed. by Alan Brown and Richard Turbet, 174-92. Cambridge: Cambridge University Press, 1992.

4. Hunter, Desmont. "The English Virginalists". In Ornaments in The New Grove Dictionary of Music and Musicians, ed. by Stanley Sadie, vol. 8: 710-2. $2^{\text {nd }}$ ed. London; New York: Oxford University Press, 2001.

5. Hunter, Desmont. "The Application of (Ornamental) Strokes in English Virginalist Music: a Brief Chronological Survey". Performance Practice Review, no. 1 (1996), article 6. DOI: 10.5642/perfpr.199609.01.06.

6. Brown, Alan. "England”. In Keyboard Music before 1700, ed. by Alexander Silbiger, 23-89. $2^{\text {nd }}$ ed. New York: Routledge, 2004.

7. Johnstone, H. Diack. "The English Beat". In Aspects of Keyboard Music: Essays in Honor of Susi Jeans, ed. by Robert C. Judd, 34-44. Oxford: Oxford University Press, 1992.

8. Johnstone, H. Diack. "Ornamentation in the Keyboard Music of Henry Purcell and his Contemporaries". In Performing the Music of Henry Purcell, ed. by Michael Burden, 82-104. Oxford: Clarendon Press, 1996.

9. Kah-Ming-Ng. "English Baroque". In Ornaments in The New Grove Dictionary of Music and Musicians, ed. by Stanley Sadie, vol. 8: 717-21. $2^{\text {nd }}$ ed. London; New York: Oxford University Press, 2001.

10. Rose, Stephen. "Performance Practice". In The Ashgate Research Companion to Henry Purcell, ed. by Rebecca Herissone, 115-64. New York: Routledge, 2012.

11. Parthenia or The Maydenhead of the first Musicke that euer was printed for the Virginalls. Composed By three famous Masters: William Byrd, $D^{r}$. John Bull, \& Orlando Gibbons, Gentilmen of his Ma ${ }^{\text {ties }}$ most Illustrieus Chapell. $<\ldots>$ Ingrauen by William Hole. [Printed at] Lond[on]: for $\mathrm{M}^{\mathrm{ris}}$. Dor: Euans. Cum privilegio. Are to be sould by G: Lowe $<\ldots$.. " [between the end of 1612 or very early in 1613 as attributed by Ferguson].

12. Di Ganassi dal Fontego, Sylvestro. Opera intilulata Fontegara la quale insegna a sonare di flauto chõ tutta l'arte opportuna a esso instrumento massime il diminuire il quale sara utile ad ogni instrumento di fiato et chorde <...> Venice: Sylvestro Ganassi, 1535.

13. Pollack, Janet. "A Reevaluation of Parthenia and its Context". PhD diss., Duke University, 2001.

14. Tallis, Thomas. Complete Keyboard Works. Urtext. Ed. by Denis Stevens. London; Frankfurt; Leipzig; New York: Edition Peters, 1953.

15. Tuttle, Stephen D., ed. Tomkins, Thomas. Keyboard Music. $2^{\text {nd }}$ ed. London: Stainer and Bell, 1973. (Musica Britannica, vol. 15)

16. Dannreuther, Edward. Musical Ornamentation. Ed. by John Stainer. 2 parts. London; New York: Novello, Ewer and Co., n. d. [c1893/95], part 1.

17. Dolmetsch, Arnold. The Interpretation of the Music of the Seventeenth and Eighteenth Centuries. Ed. by Ernest Newman. London: Novello and Company, n. d. [1915].

18. Caldwell, John. "Sources of keyboard music to 1600". In The New Grove Dictionary of Music and Musicians, ed. by Stanley Sadie, vol. 24: 19-39. $2^{\text {nd }}$ ed. London; New York: Oxford University Press, 2001.

19. Spink, Ian. "Creighton [Crichton, Creyghton], Robert (1636/7-1734)". In The New Grove Dictionary of Music and Musicians, ed. by Stanley Sadie, vol. 6: 660. $2^{\text {nd }}$ ed. London; New York: Oxford University Press, 2001.

20. Farrenc, Louise, éd. "Parthenia”. In Le Trésor des Pianistes par Aristide Farrenc, éd. par Jacques Hyppolite Aristide Farrenc. 20 vols. Paris: Farenc, Philipp; London: Cramer; Leipzig: Breitkopf \& Hærtel, 1863, vol. 6.

21. Purcell, Henry. "Rules for Graces". In Henry Purcell. A Choice Collection of Lessons for the Harpsichord or Spinnet. London: Printed on Copper-Plates for $\mathrm{M}^{\mathrm{rs}}$. Frances Purcell, <...>, 1696.

22. Farrenc, Jacques Hyppolite Aristide, éd. Le Trésor des Pianistes par Aristide Farrenc. 20 vols. Paris: Farenc, Philipp; London: Cramer; Leipzig: Breitkopf \& Hærtel, 1863, vol. 6.

23. Parthenia or the First Musick Ever Printed for the Virginals. Composed by Three Famous Masters William Byrd, Dr. John Bull, and Orlando Gibbons. Transl. into modern notation and ed. by Edward F. Rimbault. London: Musical Antiquarian Society, 1848.

24. Farrenc, Jacques Hyppolite Aristide, éd. "Pièces pour le Clavecin par Henri Purcell". In Le Trésor des Pianistes par Aristide Farrenc. 20 vols. Paris: Farenc, Philipp; London: Cramer; Leipzig: Breitkopf \& Hærtel, 1861, vol. 2.

25. The Fitzwilliam Virginal Book Edited from the Original Manuscript with an Introduction and Notes (Transl. into German by John Bernhoff) by J. A. Fuller Maitland and W. Barclay Squire. New York: Dover Publications, Inc., n. d. [1899], vol. 1. 
26. Steele, John, Francis Cameron, and Thurston Dart, eds. Bull, John. Keyboard Music: I. London: Stainer and Bell, 1960. (Musica Britannica, vol. 14).

27. Tilmouth, Michael. "York Minster MS.M.16 (s) and Captain Prendcourt". Music \& Letters 54, no. 3 (1973): 302-7. https://doi.org/10.1093/ml/LIV.3.302.

28. Corp, Edward T. "Further Light on the Career of 'Captain' François de Prendcourt”. Music \& Letters 78, no. 1 (1997): 15-23.

29. Hughes-Hughes, Augustus. Catalogue of Manuscript Music in the British Museum <...>. 3 vols. London: Longmans \& Co.; Asher \& Co.; Henry Frowde; Oxford University Press Warehouse, 1909, vol. III: Instrumental Music, Treatises, etc.

30. Beyschlag, Adolf. Die Ornamentik der Musik<...> Leipzig: Breitkopf \& Härtel, 1908.

31. Praetorius, Michael. Syntagmatis Musici <...>. 3 Bd. Wolfenbüttel: Elias Holwein, 1619, Bd. 3: Wie die Italianische und andere Termini Musici $<\ldots .$. .

32. Gabrieli, Andrea. Canzoni alla Francese für Orgel oder Cembalo, for Organ or Harpsichord. Hrsg. von Pierre Pidoux. 5 Bd. Kassel; Basel; London; New York: Bärenreiter, 1952, Bd. 5.

33. Mersenne, Marin. Harmonie Universelle. 2 parties. Paris: Pierre Ballard, 1637, pt. II, liv. 6: De L'Art de Bien Chanter.

34. Neumann, Frederick. Ornamentation in Baroque and Post-Baroque Music. With Special Emphasis on J. S. Bach. 3rd ed. Princeton: Princeton University Press, 1983.

35. Williams, Robert Forston. "Marin Mersenne: An Annotated Translation of the Fourth Treatise of the Harmonie Universelle". 3 vols. PhD diss., The University of Rochester, 1972.

36. Kuhn, Max. Die Verzierungs-Kunst in der Gesangs-Musik des 16.-17. Jahrhunderts (1535-1650). Leipzig: Breitkopf \& Härtel, 1902.

37. Attaingnant, Pierre. Magnificat sur les huit tons avec Te Deum laudamus et deux Préludes, le tout mys en tablature des Orgues, Espinettes et Manichordions <...> Paris: Pierre Attaingnant, 1530.

38. Conforti, Giovanni Luca. Breve et facile maniera d'essercitarsi a far passaggi. Roma: s. n., 1593.

39. Donington, Robert. The Interpretation of Early Music. 3rd ed. New York; London: Faber \& Faber, 1989.

40. Frescobaldi, Girolamo. Tocccate e Partite d'Intavolatura $<\ldots\rangle$ Libro primo. Roma: Niccolo Borboni, 1615.

41. Frescobaldi, Girolamo. Il Secondo Libro di Toccate <...> Roma: Nicolo Borboni, 1637.

42. Diruta, Girolamo. Il Transilvano dialogo sopra il vero modo di sonar: Organi, \& Istromenti da penna $<\ldots>$ Venezia: Alessandro Vincenti, 1597.

43. Diruta, Girolamo. Il Transilvano $(1593,1609)$. A facsimile edition, with introduction by Edward J. Soehnlen and Murray C. Bradshaw. Buren: Frits Knuf, 1983.

44. Sancta Maria, Thomas, de. The Art of Playing the Fantasia (Libra Llamado El Arte de Taner Fantasia). Transl., transcription, comment. by Almonte C. Howell Jr. and Warren E. Hultberg. 2 vols. Pittsburg: Latin American Literary Review Press, 1991.

45. Cavalieri, Emilio, del. La rappresentatione di anima, et di corpo <...> Roma: Nicolò Mutij, 1600.

Received: September 2, 2019 Accepted: November 28, 2019

Authors'information:

Alexei A.Panov - Dr. Habil., Professor; a.panov@spbu.ru Ivan V.Rosanoff - Dr. Habil., Professor; i.rozanov@spbu.ru 